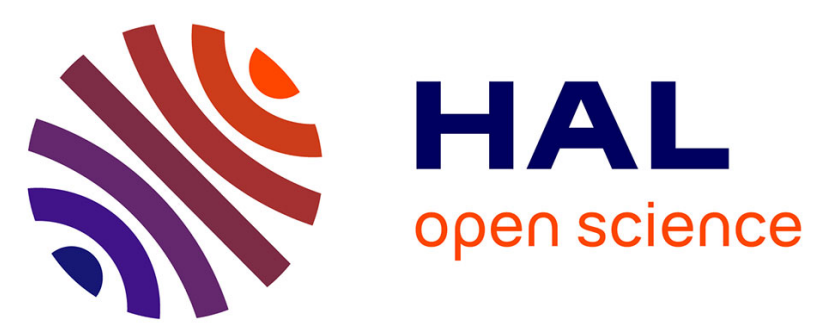

\title{
Olive groves around the lake. A ten-thousand-year history of a Cretan landscape (Greece) reveals the dominant role of humans in making this Mediterranean ecosystem
}

Isabelle Jouffroy-Bapicot, Tiziana Pedrotta, Maxime Debret, Sophie Field, Roberto Sulpizio, Giovanni Zanchetta, Pierre Sabatier, Neil Roberts, Willy Tinner, Kevin Walsh, et al.

\section{To cite this version:}

Isabelle Jouffroy-Bapicot, Tiziana Pedrotta, Maxime Debret, Sophie Field, Roberto Sulpizio, et al.. Olive groves around the lake. A ten-thousand-year history of a Cretan landscape (Greece) reveals the dominant role of humans in making this Mediterranean ecosystem. Quaternary Science Reviews, 2021, 267, pp.107072. 10.1016/j.quascirev.2021.107072 . hal-03468246

\author{
HAL Id: hal-03468246 \\ https://hal.science/hal-03468246
}

Submitted on 21 Dec 2021

HAL is a multi-disciplinary open access archive for the deposit and dissemination of scientific research documents, whether they are published or not. The documents may come from teaching and research institutions in France or abroad, or from public or private research centers.
L'archive ouverte pluridisciplinaire HAL, est destinée au dépôt et à la diffusion de documents scientifiques de niveau recherche, publiés ou non, émanant des établissements d'enseignement et de recherche français ou étrangers, des laboratoires publics ou privés. 


\title{
Olive groves around the lake. A ten-thousand-year history of a Cretan landscape (Greece) reveals the dominant role of humans in making this Mediterranean ecosystem
}

\author{
Isabelle Jouffroy-Bapicot ${ }^{\text {a, b, 1, * }}$, Tiziana Pedrotta ${ }^{c}$, Maxime Debret ${ }^{\mathrm{d}}$, Sophie Field ${ }^{\mathrm{e}}$, \\ Roberto Sulpizio ${ }^{\mathrm{f}}$, Giovanni Zanchetta ${ }^{\mathrm{g}}$, Pierre Sabatier ${ }^{\mathrm{h}}$, Neil Roberts ${ }^{\mathrm{e}}{ }^{\mathrm{i}}$, Willy Tinner ${ }^{\mathrm{c}}$, \\ Kevin Walsh ${ }^{\mathrm{j}, \mathrm{k}}$, Boris Vannière ${ }^{\mathrm{a}, \mathrm{b}, 1,{ }^{* *}}$ \\ a Chrono-environnement, UMR 6249 CNRS, University Bourgogne Franche-Comté, Besançon, France \\ ${ }^{\mathrm{b}}$ MSHE, UAR 3124 CNRS, University Bourgogne Franche-Comté, Besançon, France \\ ${ }^{\mathrm{c}}$ Institute of Plant Sciences and Oeschger Centre for Climate Change Research, University of Bern, Switzerland \\ ${ }^{\mathrm{d}}$ Morphodynamique Continentale et Côtière, UMR 6143 CNRS, University of Rouen, France \\ e School of Geography, Earth and Environmental Sciences, University of Plymouth, UK \\ ${ }^{\mathrm{f}}$ Dipartimento di Scienze Della Terra e Geoambientali, Bari, Italy \\ ${ }^{\mathrm{g}}$ Dipartimento di Scienze Delle Terra, University of Pisa, Pisa, Italy \\ ${ }^{\mathrm{h}}$ EDYTEM, UMR 5204 CNRS, University of Savoie Mont-Blanc, University of Grenoble Alpes, Le Bourget Du Lac, France \\ ${ }^{\mathrm{i}}$ School of Archaeology, University of Oxford, UK \\ ${ }^{\mathrm{j}}$ Department of Archaeology, University of York, UK \\ ${ }^{\mathrm{k}}$ Institute for Advanced Study (IMéRA), Aix-Marseille University, Marseille, France
}

\section{A R T I C L E I N F O}

\section{Article history:}

Received 25 January 2021

Received in revised form

28 June 2021

Accepted 28 June 2021

Available online $\mathrm{xxx}$

Handling Editor: Donatella Magri

\section{Keywords:}

Paleoecology

Anthropisation

Human impacts

Olive grove

Holocene

Crete

Mediterranean

Socio-ecosystem

Land-use

Biodiversity

\begin{abstract}
A B S T R A C T
The reconstruction of millennial-scale interactions between ecosystems and societies can provide unique and valuable references for understanding the creation of cultural landscapes and help elucidate their value, weaknesses and legacies. Among the most emblematic forms of Mediterranean land use, olive groves and pastoralism have occupied a prominent place. Therefore, it is vital to know when, how, and with what ecological consequences these practices were established and developed. Located in the southern part of the Aegean Sea, Crete is the largest island of Greece. The island is characterised by a long human history of land use, but our understanding of past environmental changes for the entire Holocene is fragmentary. This paper presents a new investigation of Lake Kournas in Crete, where recent coring provided a 15-m sequence covering ten millennia of land cover and land-use history. The study of this new core involves the analysis of the sediment dynamics, flood deposits, pollen, diatoms, fungal and algal remains, and microcharcoals. Results show that ecosystem development near Lake Kournas was not a linear process. They reveal linkages and feedbacks between vegetation, biodiversity, fire, human impact, erosion, and climate change. A possible human occupation and agro-pastoral activities around the lake may have been detected as early as 9500 cal BP, perhaps in a transitional phase between the Mesolithic and the Neolithic. At 8500 cal BP, climatic conditions may have promoted the expansion of the evergreen oak woodland. However, human impact was probably the most important driver of ecosystem change with the establishment of an agro-system after 8000 years ago. Thereafter, the trajectory of Kournas' lake and catchment ecosystems from the Mid to Late Holocene follow the rhythm of land-use change. Among the traditional Mediterranean land uses, olive cultivation locally played a major role in the socioecosystem interactions, providing economic benefits but also destabilising soils. During the last six millennia, three main phases of olive cultivation occurred during the Final Neolithic-Minoan period, the Hellenistic-Roman-Byzantine (HRB) period and Modern times. Along with the changing land use under the successive political and economic influences rules, the resilience capacities of vegetation permitted it to shift back to higher biodiversity again after decreasing phases. Forest vegetation was always able to
\end{abstract}

\footnotetext{
* Corresponding author. Chrono-environnement, UMR 6249 CNRS, University Bourgogne Franche-Comté, Besançon, France.

** Corresponding author. MSHE, UAR 3124 CNRS, University Bourgogne Franche-Comté, Besançon, France.

E-mail addresses: isabelle.jouffroy@univ-fcomte.fr (I. Jouffroy-Bapicot), boris.vanniere@univ-fcomte.fr (B. Vannière).

1 IJB and BV contributed equally to this work.
} 
recover until the onset of the Venetian period (13th century), when woodlands were dramatically reduced. Only during the past century has forest vegetation slightly recovered, while the flood regime had already been altered during previous centuries. During the past 100 years, biodiversity markedly declined, probably in response to the industrialization of agriculture.

๑) 2021 Published by Elsevier Ltd.

\section{Introduction}

One of the main current environmental challenges is the possible response of socio-ecosystems to global change, including climate warming (IPCC Report, 2019) and a dramatic trend of biodiversity loss (IPBS Report, 2019). The Mediterranean is a hot spot of global change (e.g. Giorgi, 2006), and its islands are especially threatened by these ongoing environmental issues, as is the case for the Aegean Islands (Vogiatzakis et al., 2016). Extreme events such as drought, megafire, flood or storminess are already affecting Mediterranean anthropo-systems, but their magnitude and frequency are expected to intensify in the coming years (e.g. Sarris et al., 2014; Tapoglou et al., 2019). Moreover, because of past climate changes and millennial land-use history, Mediterranean biodiversity and soils can be highly vulnerable to erosion (e.g. Collins et al., 2010; Walsh et al., 2019), putting Mediterranean landscapes and associated resources in danger.

The reconstruction of millennial ecological dynamics can provide key documents for understanding the processes of long-term interaction between ecosystems and societies, and their present legacies. They document land-cover change and land-use practices that shaped the cultural landscape and may explain their value and weaknesses (e.g. Whitlock et al., 2018). Among the most emblematic Mediterranean land uses, olive groves and pastoralism have occupied a prominent place. Therefore, it is vital to know when, how, and with what ecological consequences these practices were established and developed. Furthermore, the relationship between socio-environmental changes and the Holocene climate - notably during the major climate transitions (e.g. Magny et al., 2013; Cheng et al., 2015; Finné et al., 2019; Azuara et al., 2020) or Rapid Climate Changes (Mayewski et al., 2004) is a hot debate in the archaeology and paleoecology scientific communities and echo present-day challenges. In the eastern Mediterranean, recent studies emphasise and/or attempt to model the role of climate changes on societies and their practices (e.g. Weninger et al., 2009; Kaniewski et al., 2013; Wiener, 2014; Rohling et al., 2019) or on the opposite side criticize and demonstrate the limits of deterministic scenarios (e.g. Knapp and Manning, 2016; Chapman, 2018). Societal development and environmental changes linkages have been investigated at a regional scale in Southern Greece, based on palaeoenvironmental archives and archaeological sites (e.g. Izdebski et al., 2020; Kouli et al., 2018, Weiberg et al., 2016, 2019). They highlighted regional trends but they also underlined the importance of local-scale welldocumented sequences to better understand adaptive strategies of human society to environmental changes.

Located in the southern part of the Aegean Sea, Crete is the largest island of Greece characterised by many landscape types along an altitudinal gradient from the seashore up to mountains: the White Mountains in the West, Psiloritis in central Crete and Dikti mountains in the East. The island is well known for its numerous endemic plants, but it also has a very long history marked by numerous human colonisations and cultural changes (Rackham and Moody, 1996). Today, the threats to ecosystems are mainly due to tourism and population growth on coastal areas, overgrazing on the mountain slopes and intensive agricultural practices in lowlands in which olive groves have an important place (e.g. Ispikoudis et al., 1993; Fielding and Turland, 2008; Kosmas et al., 2016). For decades, the focus of archaeological investigation in Crete has been Minoan civilisation (c.5000-3000 cal BP), wich includes the important archaeological sites of Knossos, Malia, Phaistos in Central Crete, Patras in East Crete and Chania in West Crete (Cline, 2010). Recent investigations highlight numerous other archaeological sites over time and space, although they are generally less well documented than those of the Bronze Age (e.g. Nowicki, 2014; Rackham and Moody, 1996). Our current understanding of past vegetation and environmental changes during the Holocene is based on only a few sedimentary archives and pollen analyses. Apart from a two millennia peat bog sequence located in the White Mountains (Atherden and Hall, 1999; Jouffroy-Bapicot et al., 2016), most palynological records available are located in the coastal lowland areas of Crete (Moody et al., 1996; Bottema and Sarpaki, 2003), the most recent being performed in the framework of geomorphological studies of the littoral floodplains near important archaeological settlements such the Minoan sites of Phaistos (Ghilardi et al., 2018, 2019), or Palaikastro (Cañellas-Boltà et al., 2018). The chronology of these sequences is often limited in duration, documenting short time-window histories, and until now, no published sequence covers the entire Holocene environmental history of Crete. However, Bottema and Sarpaki (2003) highlighted the great potential of Lake Kournas for palaeoecological studies. This paper presents a new investigation of the lake where recent coring provided a $15-\mathrm{m}$ sequence covering ten millennia of land cover and land-use history. The study of this new core involves the analysis of the sediment dynamics, flood deposits, pollen grains, fern spores, fungal, algal and diatom remains, and microcharcoals. This paper has three main goals: 1 ) to propose a detailed and multiproxy reconstruction of environmental changes in the surrounding of the lake for the last 10 millennia, 2) to document the long history of human occupation and practices in this region, 3) to discuss the respective role of land use and climate changes on ecosystem dynamics, i.e. on soil erosion, fire and flood regime, lake productivity, land cover and plant biodiversity.

\section{Regional setting}

Located in the north-western part of Crete, Lake Kournas is the only natural lake on the island. Situated about $3 \mathrm{~km}$ from the coast Fig. 1, in the foothills of the White Mountains (Lefká Óri), at the southeast of the Peninsula of Chania, the lake covers an area of about $1 \mathrm{~km}^{2}$ (Fig. 1A). It is fed by freshwater springs from the mountains, with the major one located below the lake level on the south side of the basin. In addition, two small ephemeral rivers to the south and west bring inflow during intense rainfall episodes. The lake feeds the Delphinos River which runs north to the sea. The central deep basin has a water depth of around $21-22 \mathrm{~m}$, and the shores of the lake are characterised by carbonate shelfs that extend up to $5 \mathrm{~m}$ in water depth towards the lake centre and are covered by a maximum of $5 \mathrm{~m}$ of water. (Fig. 1C). The lake contains freshwater with slightly elevated electrical conductivity (salinity) values up to $\sim 1500 \mu \mathrm{S} \mathrm{cm}^{-1}$, and water levels fluctuate seasonally by of up to 

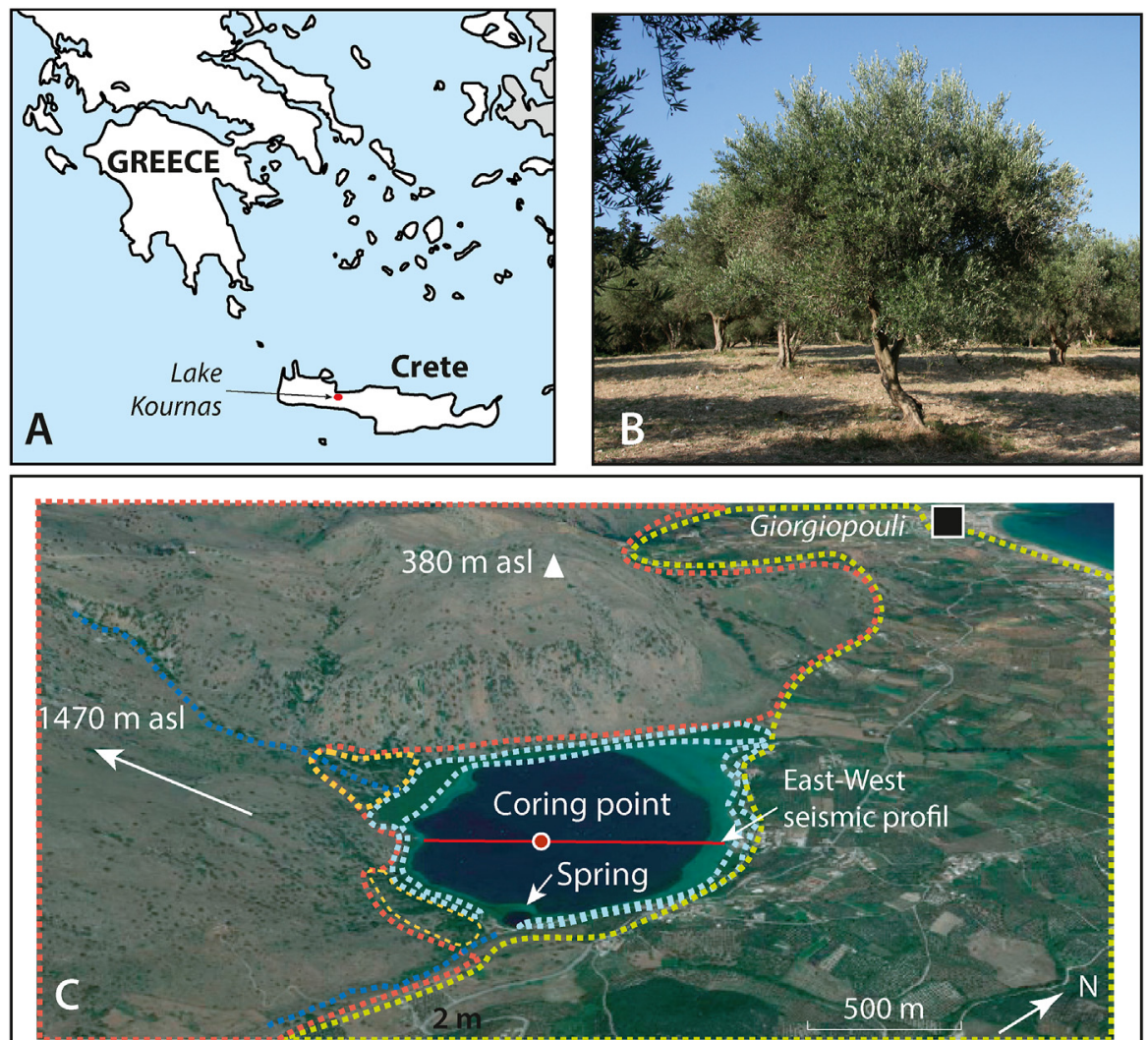

\section{....... Temporary inlet}

Littoral vegetation (Vitex agnus-castus, Vitis vinifera...)

Sclerophyllous woodland (Styrax, Q. Coccifera, Phlomis sp., ...)

Olive groves dominating \& crops (Olea europea, Cerealia sp., ...)

Garrigue to Phrygana (Q. coccifera, Ceratonia cilica, Phlomis sp., Calicotome villosa, Sarcopoterium spinosum...)
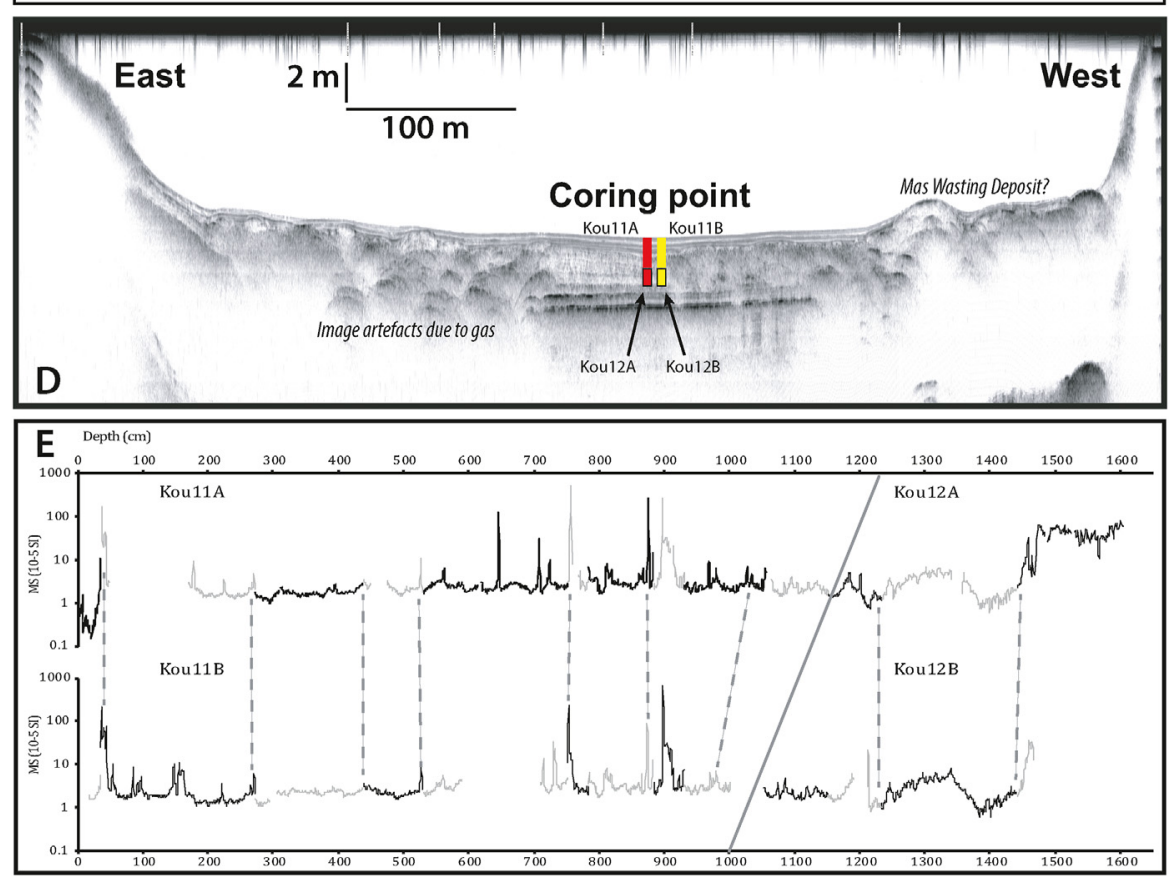

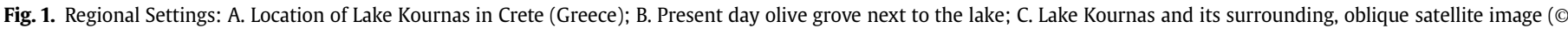

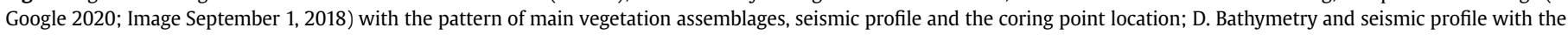

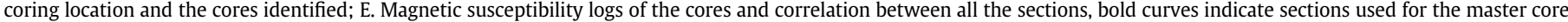
studied thereafter with other proxies. 
$4 \mathrm{~m}$. The lake itself has been the subject of several previous scientific studies, focusing especially on its aquatic biota (e.g. Vallianos et al., 1985; Tigilis, 2007).

The lake surroundings consist of two main zones: steep slopes to the west and south and a flat cultivated and inhabited area to the north-eastern part. The south-western part mainly consists of crystalline limestone, more or less karstic, while the north-eastern part consists of Miocene marine limestone (e.g. PomoniPapaioannou and Karakitsios, 2002). Garrigue and phrygana dominate the vegetation of the slopes with patches of sclerophyllous woodlands near the lake, the flat zone is dominated by olive groves (Fig. 1B), with some vineyards and cultivated fields. Finally, a dense scrub littoral vegetation covers the lake perimeter, mainly composed of chaste tree (Vitex agnus-castus) and wild-grape vine (Vitis vinifera subsp. Sylvestris) (Fig. 1C). The climate of Crete is typically Mediterranean, with cool and moist winters and hot and dry summers. West Crete, exposed to Atlantic flux, is the moister part of the island, especially the White Mountains which have the highest precipitation in Crete, including snow (Agou et al., 2019).

\section{Material and method}

\subsection{Coring}

The Aegean area in general, and Crete in particular, are located near the Hellenic subduction zone which are subject to seismic activity, earthquakes, tsunamis and volcanism (e.g. Jusseret et al., 2013). Thus, before coring, a seismic reflection survey was conducted using a single-channel $3.5 \mathrm{kHz}$ pinger source and it provided the lake bathymetry and several high-resolution sub-bottom profiles, which were used to establish the seismic stratigraphy of the best preserved part of the basin's sediments. The digital acquisition was achieved by a stratabox SyQwest system (HighResolution Echo Sounders and Acoustic Systems for Precision lake floor Exploration) and conventional GPS positioning (Fig. 1D). Coring operations were directly guided by the images of the subsurface sedimentary accumulation; two overlapping parallel cores were taken in the deep basin (water depth: 21-22 m) within the well-stratified seismic units and avoiding chaotic Mass Wasting Deposits (MWD). The sediment-water interface was successfully recovered using a gravity corer (short core ca. $1 \mathrm{~m}$ length). Longer sediment cores were retrieved with a $3 \mathrm{~m}$ long UWITEC piston system operating from a floating platform. This study refers to the overlapping twin cores Kou11 A and B, taken in 2011, and Kou12 A and B, taken in 2012 . Core coordinates are: $35.329715^{\circ}$ latitude and $24.275945^{\circ}$ longitude. The twin cores retrieved in 2011 cover the top $11 \mathrm{~m}$ of the lake sedimentation, while the maximum depth reached in 2012 was $16 \mathrm{~m}$ below the water-sediment interface (Fig. 1D).

\subsection{Dating}

The chronology is based on a combination of radiometric markers derived from short-lived radionuclides $\left({ }^{210} \mathrm{~Pb}\right.$ and $\left.{ }^{137} \mathrm{Cs}\right)$ for the topmost $25 \mathrm{~cm}$ of the sediment record, and of 28 AMS ${ }^{14} \mathrm{C}$ ages measured on terrestrial plant macrofossils (leaves, seeds, charcoals and wood; Table 1; Figs. 3 and 4) sampled on the master core (see the following text section). For radiocarbon analyses, selected terrestrial macrofossils were isolated from sediment samples (thickness of $1 \mathrm{~cm}$ ) by wet-sieving through a $100 \mu \mathrm{m}$ mesh. All radiocarbon ages were calibrated with the Intcal13.14C calibration set (Reimer et al., 2013). Based on these chronological markers, Clam package (R software, R. Core Team 2018) was used to generate an Age Depth Model within a 95\% confidence explicate and using a smooth cubic spline model (Blaauw, 2010).
The short-lived radionuclides on the core Kou11-P1 were measured using well-type Ge detectors at the Modane Underground Laboratory (LSM; Reyss et al., 1995; Fig. SM5). The measurement intervals followed sedimentary unit boundaries and resulted in a non-regular sampling of approximately $1 \mathrm{~cm}$. The isotope ${ }^{137} \mathrm{Cs}$ was accidently introduced into the environment at the end of the 1950s as a by-product of atmospheric nuclear weapons tests (peak at $1963 \mathrm{CE}$ ) and during the Chernobyl accident in 1986 CE (Appleby et al., 1991). ${ }^{210} \mathrm{~Pb}$ excess was calculated as the difference between total ${ }^{210} \mathrm{~Pb}$ and ${ }^{226} \mathrm{Ra}$ activities. The chronological for short-lived radionuclides was established with the serac R package (Bruel and Sabatier, 2020).

\subsection{Sediment analysis}

The cores were horizontally split in two halves, scanned and logged in detail for magnetic susceptibility, spectrophotometry and X-ray fluorescence, and thereafter sub-sampled for discrete analyses: grain size and energy-dispersive spectrometry. Magnetic susceptibility (MS; Figs. 1E, 2 and 3) was measured at $5 \mathrm{~mm}$ stratigraphic-resolution with an MS2E1 surface-scanning sensor from Bartington Instruments mounted on a Geotek multi-sensor core logger (Vannière et al., 2004). These analyses, performed on all split-core sections, allowed us to establish stratigraphic correlations between them and construct the master core (Kou11$12 \mathrm{MC}$ ), guaranteeing complete records without any gaps (Fig. 1E).

Grain Size (GS; Figs. 2 and 3 and SM1) measurements were undertaken on 312 samples distributed at an average of $5 \mathrm{~cm}$ along the whole sequence and using a laser diffraction particle analyzer (LS230 Beckman-Coulter). Before analysis and for all samples, $1 \mathrm{~cm}^{3}$ of wet sediment was digested in a $30 \%$ solution of hydrogen peroxide to remove organic matter. The residual mineral fraction was finally dispersed in a solution of sodium-hexametaphosphate by ultrasonic treatment. A few samples were not analysed for grain-size because they were destroyed during chemical processing.

Spectrophotometric (SP; Fig. 3 and SM2) data have been obtained by the measurement of sediment reflectance at $1 \mathrm{~cm}$ stratigraphic intervals with a Minolta CM $2600 \mathrm{~d}$. The illuminant was D65, which corresponds to average daylight, and the wavelengths belong to the extended visible domain from 360 to $740 \mathrm{~nm}$. The measurement aperture was set to $8 \mathrm{~mm}$ and the step of measurement to $1 \mathrm{~cm}$. By taking the optical lightness $\mathrm{L}_{-}$(White/Black) vs $700 / 400$ ratio, it is possible to distinguish the different sedimentary end members that constitute the sediment (Mix et al., 1992; Debret et al., 2011). Unfortunately, a few limited parts of the sequence do not have SP data because they were sub-sampled before spectrophotometric measurements were taken, hence the gaps in the Q7/4 and $\mathrm{L} *(\mathrm{D} 65)$ profiles in Fig. 3.

X-Ray Fluorescence (XRF; Figs. 2 and 3 and SM3) analysis was performed on the split core-sections' surface at a $1 \mathrm{~cm}$ stratigraphic interval in two distinct runs using a non-destructive Avaatech core scanner. The relative geochemical contents (intensities), expressed in counts per second, were obtained at two tube settings: $10 \mathrm{kV}$ at $1.5 \mathrm{~mA}$ for $\mathrm{Al}, \mathrm{Si}, \mathrm{S}, \mathrm{Cl}, \mathrm{K}, \mathrm{Ca}, \mathrm{Ti}, \mathrm{Mn}$ and $\mathrm{Fe}, 30 \mathrm{kV}$ at $1 \mathrm{~mA}$ for $\mathrm{Br}, \mathrm{Sr}$, $\mathrm{Rb}, \mathrm{Zr}$ and $\mathrm{Pb}$, and each run lasting $60 \mathrm{~s}$. Because of the influences of variable water content and grain size on the sediment matrix, the XRF scanner only provides a relative estimation of geochemical variables, and the acquired counts are semi-quantitative (Tjallingii et al., 2007). Therefore, normalization of element counts to the total count numbers was completed to partially correct drifts (Revel et al., 2010). Only elements that offer a significant variability without too much noise are presented in this paper. The sedimentary unit "Pebbles" was not measured for XRF and MS analyses.

Complementary geochemical analyses were performed on a few 
Table 1

Dates from cores Kou11 and Kou12. Radiocarbon ages calibration has been done with the IntCal13 calibration curves (Reimer et al., 2013).

\begin{tabular}{|c|c|c|c|c|c|c|}
\hline Core section & Section Depth $(\mathrm{cm})$ & Core Depth (cm) & Material & Reference & Age $14 \mathrm{C}$ & Age cal BP** \\
\hline Kou11 P1 & 5.38 & 0.12 & Sediment & $210 \mathrm{~Pb}$ & & $-60 \pm 1$ \\
\hline Kou11 P1 & 8.28 & 3.28 & Sediment & $210 \mathrm{~Pb}$ & & $-36 \pm 2$ \\
\hline Kou11 P1 & 11.28 & 6.78 & Sediment & $137 \mathrm{Cs}$ & & $-13 \pm 2$ \\
\hline Kou11 P1 & 15.05 & 10.55 & Sediment & $210 \mathrm{~Pb}$ & & $20 \pm 5$ \\
\hline Kou11 P1 & 19.03 & 14.53 & Sediment & $210 \mathrm{~Pb}$ & & $50 \pm 6$ \\
\hline Kou11 P1 & 29.50 & 25.00 & Charcoal & Poz-64195 & $255 \pm 30$ & $300 \pm 77$ \\
\hline Kou11 B1 (1) & 64.50 & 69.40 & Wood & Poz-43409 & $1295 \pm 30$ & $1232 \pm 55$ \\
\hline Kou11 B1 (2) & 76.50 & 190.30 & Wood-Vitex & Poz- 43410 & $2005 \pm 30$ & $1959.5 \pm 78.5$ \\
\hline Kou11 A1 (2) & 5.50 & 268.40 & Wood & Poz-46471 & $2235 \pm 30$ & $2245 \pm 92$ \\
\hline Kou11 A1(2) & 66.00 & 326.70 & Charcoal & Poz-64194 & $3420 \pm 90$ & Rejected \\
\hline Kou11 B2(1) & 138.50 & 376.20 & Wood & Poz- 48228 & $2860 \pm 80$ & Rejected \\
\hline Kou11 A2(1) & 80.50 & 476.60 & Wood & Poz-45626 & $2745 \pm 35$ & Rejected \\
\hline Kou11 A2(1) & 87.50 & 481.00 & Wood & Poz-43411 & $2680 \pm 35$ & Rejected \\
\hline Kou11 A2(2) & 15.00 & 544.60 & Charcoal & Poz-64193 & $2640 \pm 40$ & Rejected \\
\hline Kou11 A2 (2) & 101.50 & 624.70 & Wood-Bark & Poz-45628 & $2620 \pm 35$ & $2729 \pm 108$ \\
\hline Kou11 A2 (2) & 135.50 & 652.30 & Wood & Poz-45684 & $2645 \pm 35$ & $2786.5 \pm 57.5$ \\
\hline Kou11 B3 (1) & 44.50 & 653.00 & Charcoal & Poz-43412 & $2745 \pm 35$ & $2844 \pm 81$ \\
\hline Kou11 A3 (1) & 68.50 & 714.00 & Wood & Poz- 48229 & $3225 \pm 35$ & $3464.5 \pm 91.5$ \\
\hline Kou11 B3.2 & 65.50 & 766.20 & Charcoal + Macroremains & Poz-64196 & $3670 \pm 30$ & $4005 \pm 90$ \\
\hline Kou11 A3.2 & 45.00 & 807.90 & Charcoal & Poz-63618 & $4090 \pm 40$ & $4603 \pm 152$ \\
\hline Kou 11 A3.2 & 46.50 & 808.40 & Wood & Poz-43413 & $4065 \pm 35$ & $4618.5 \pm 182.5$ \\
\hline Kou11 A3 (2) & 140.00 & 893.90 & Seed & Poz-45625 & $4610 \pm 40$ & $5271 \pm 196$ \\
\hline Kou12 B3 (2) & 28.50 & 909.90 & Charcoal & Poz-64198 & $5160 \pm 80$ & $5916 \pm 200$ \\
\hline Kou12 B3 (2) & 81.00 & 954.20 & Charcoal + Macroremains & Poz-64197 & $5600 \pm 80$ & $6389 \pm 147$ \\
\hline Kou12 A4 (1) & 96.50 & 980.90 & Seed & Poz-52617 & $5565 \pm 35$ & $6351 \pm 56$ \\
\hline Kou12 A4 (1) & 132.50 & 1005.40 & Wood & SacA 31,009 & $5850 \pm 45$ & $6657.5 \pm 121.5$ \\
\hline Kou12 B4 (1) & 20.00 & 1040.90 & Charcoal + Macroremains & Poz-64201 & $6540 \pm 80$ & $7452 \pm 136$ \\
\hline Kou12 B4 (1) & 36.00 & 1053.50 & Wood & SacA 31,010 & $6520 \pm 35$ & $7416.5 \pm 87.5$ \\
\hline Kou12 B4 (1) & 80.00 & 1097.10 & Charcoal + Macroremains & Poz-64200 & $7240 \pm 100$ & $8069 \pm 151$ \\
\hline Kou12 B4 (2) & 81.50 & 1218.50 & Wood & Poz-52318 & $8370 \pm 50$ & $9380 \pm 115$ \\
\hline Kou12 B4 (2) & 86.00 & 1224.00 & Charcoal & Poz-52319 & $8390 \pm 50$ & $9396 \pm 106$ \\
\hline Kou12 A5 (1) & 87.50 & 1230.50 & Charcoal & Poz-48602 & $8470 \pm 50$ & $9479.5 \pm 61.5$ \\
\hline Kou12 A5 (1) & 90.50 & 1233.50 & Wood & SacA 31,008 & $8540 \pm 40$ & $9514 \pm 35$ \\
\hline
\end{tabular}

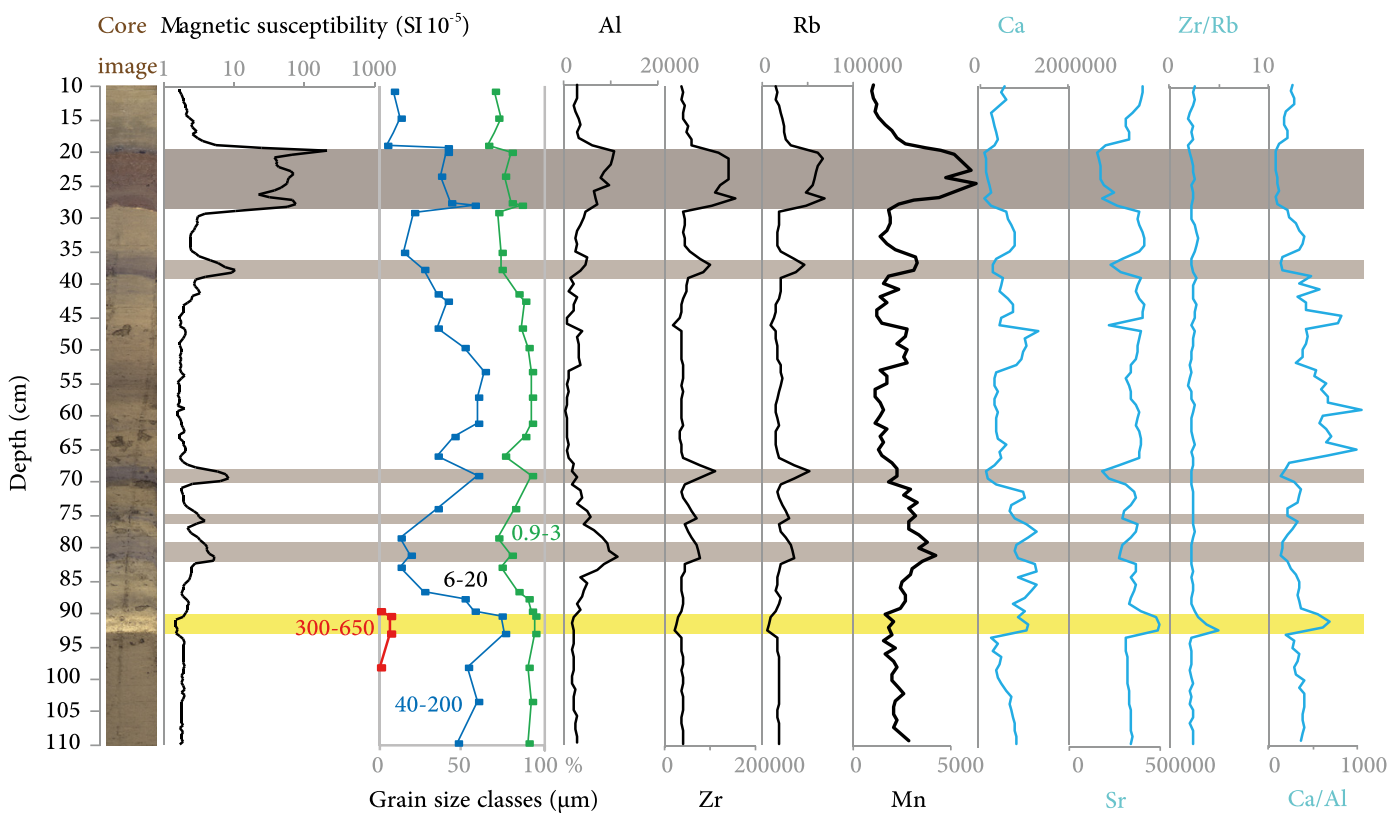

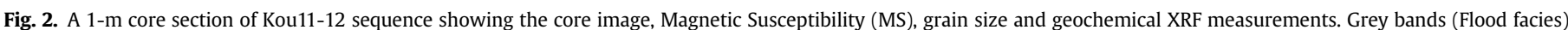

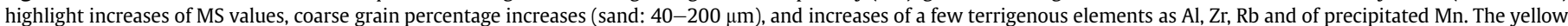

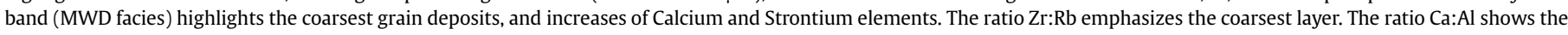
biogenic carbonate content. (For interpretation of the references to colour in this figure legend, the reader is referred to the Web version of this article.)

localised samples after looking for glass shards as a proxy for crypto-tephra deposition (Fig. SM6). Initially, a contiguous $5 \mathrm{~cm}$ thick sub-sampling was taken; if glass shards were observed, then sampling was decreased to $1 \mathrm{~cm}$ intervals. To isolate and observe the glass shards, each sample was treated with a $10 \%$ solution of acetic acid to remove carbonates, and a $35 \%$ solution of hydrogen peroxide to remove organic matter. Then, the samples were sieved at $40 \mu \mathrm{m}$. Particles larger than $40 \mu \mathrm{m}$ were further separated into 


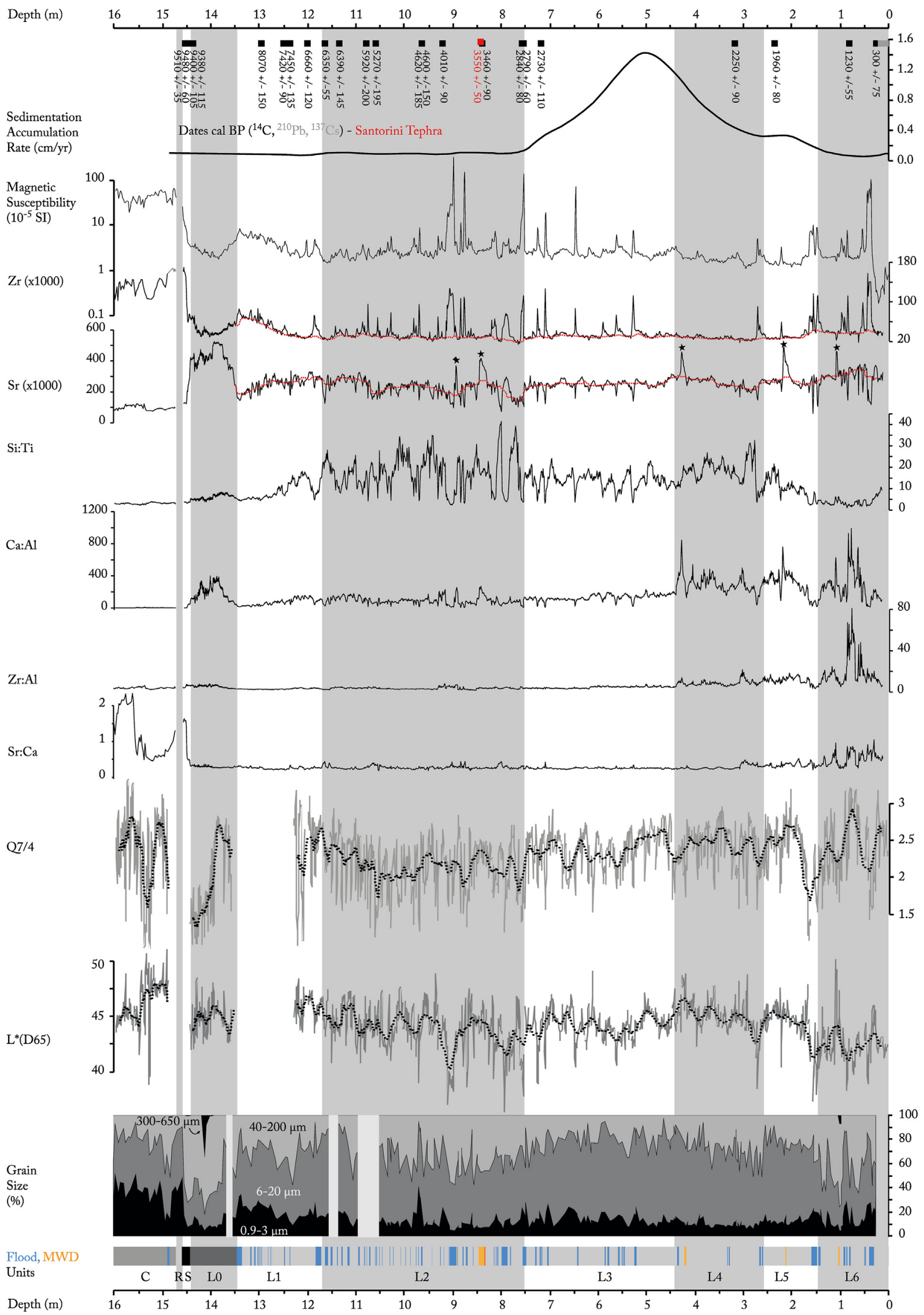

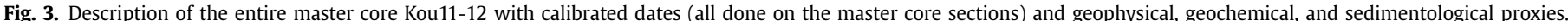

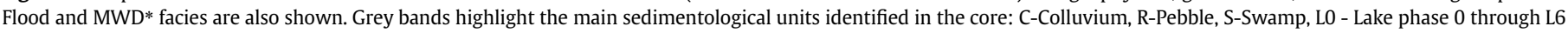

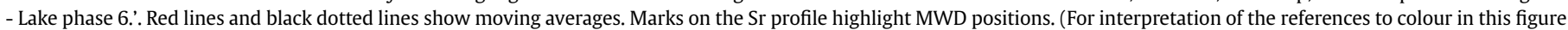
legend, the reader is referred to the Web version of this article.) 
two groups using the density separation method (Blockley et al., 2005). Particles with a density lower than 2.5 have were with a binocular lens and an optical microscope. Thereafter, energydispersive spectrometry (EDS) analyses of the glass shards were performed using an EDAX-DX micro-analyzer mounted on a Philips SEM 515. The ZAF correction procedure does not include natural or synthetic standards for reference and requires analysis normalization at a given value (which is chosen at 100\%). Analytical precision is $0.5 \%$ for abundances higher than $15 \mathrm{wt} \% 1 \%$ for abundances around $5 \mathrm{wt} \%, 5 \%$ for abundances of $1 \mathrm{wt} \%$ and less than $20 \%$ for abundances close to the detection limit (around $0.5 \mathrm{wt} \%$ ). Interlaboratory standards include ALV981R23 (basalt), CFA47 (trachyte), KE12 (pantellerite, Cioni et al., 1998). Measurement accuracy of is around $1 \%$, a value analogous to that obtained using WDS, as tested by Marianelli and Sbrana (1998). Comparison of EDS and WDS micro-analyses carried out on the same samples showed differences of less than $1 \%$ for abundances greater than $0.5 \mathrm{wt} \%$.

\subsection{Biostratigraphic analyses}

For the analyses of pollen and non-pollen palynomorphs (NPPs), sub-samples were taken at mean intervals of 100 years on the lowest two-thirds of the core, and from 50 to 10 years on the upper part, producing a total of 140 samples. Samples were prepared according to standard techniques described by Faegri and Iversen (1989) adapted to the protocol used in the Chronoenvironnement laboratory, Besançon, France. Half of the samples were analysed at the IPS and OCCCR laboratory, Bern, Switzerland and at the Chrono-environnement laboratory, Besançon, France for the other half. An average of 400 total land pollen (TLP) was achieved. Pollen grains were identified with the aid of keys and photographs (Reille, 1999; Chester and Raine, 2001; Beug, 2004) and reference to each of the two laboratories' modern pollen collections. Identified and counted NPPs here are algal and fungal remains. They were identified using published descriptions and photographs (Jankovská and Komárek, 2000; van Geel, 2001; van Geel and Aptroot, 2006; Cugny et al., 2010), and counting followed recommendations in Etienne and Jouffroy-Bapicot (2014). NPPs are expressed in accumulation rates $\left(\# / \mathrm{cm}^{2} / \mathrm{yr}\right)$. The pollen, fungal and algal remains diagrams were constructed using Tilia Graph (Grimm, 1991-2018). Pollen are expressed as percentages of the Total Land Pollen (TLP), fern spores, aquatic and hygrophilous taxa being excluded from the TLP sum. Zone boundaries were identified using CONISS, based on the square root transformation of the stratigraphically constrained data set, respectively, the TLP-, the total fungal remains- and the total algal remains sums.

For the microscopic charcoal analysis, 177 sub-samples were taken at mean intervals of 55 yrs and prepared following the method described in Doyen et al. (2016); counting followed Finsinger and Tinner (2005).

Preparation of the 50 samples for diatom analysis followed standard methods adapted from Battarbee et al. (2001), with 300 diatom valves counted on each slide where possible. Full details are reported in Field (2015). Species identification is based on Krammer and Lange-Bertalot (1991a, 1991b; 1997a; 1997b; 2000), hereafter KLB. Zone boundaries were identified using CONISS and transfer function training sets provided by the European Diatom Database (EDDI) (Juggins, 2015). The combined salinity training set was used by weighted averaging with inverse deshrinking and carried out using C2 software (Juggins, 2003-2006). Detrended Correspondence Analysis (DCA) was used to assess the similarity between the species and the samples using the software PC-ORD.

All samples analysed for the bio-proxies are free of sedimentary event deposits that correspond to rapid accumulation layers like flood deposits and Mass Wasting Deposits (MWD, see section 4.1.1.).

\subsection{Pollen diversity}

We used a statistical analysis that has been successfully developed and/or tested in different areas to calculate pollen richness and evenness as described in Colombaroli and Tinner (2013). We used rarefaction analysis to estimate the number of pollen taxa that would be encountered if the pollen sum was to be kept constant (Birks and Line, 1992), which is the pollen richness, and we used the probability of interspecific encounter to estimate the palynological evenness. The pollen sum for each sample was standardized on the minimum pollen sum $(n=363)$. We also calculated an evennessdetrended palynological richness to evaluate the effect of palynological evenness on richness (Colombaroli and Tinner, 2013). All analyses were performed with the program R statistics ( $R$ Development Core Team 2018).

\section{Results}

\subsection{Sedimentary dynamics}

\subsubsection{Sedimentary units}

Fig. 1E shows the Magnetic Susceptibility (MS) records for the two cores Kou11 and Kou12 and highlights the main correlations between them. These correspondences allowed all the core sections to be tied together to construct the master core, which was subsequently used for further analysis. XRF recordings of the core sections confirmed these correlations. For the main part of the record, Lake Kournas' sedimentation is dominated by a light brown silty carbonate marl with an important in-situ biochemical component of either carbonate or biogenic silicate precipitates (Fig. 2). Binocular microscope observations of sediments allowed us to identify micrite, algal oncoids and plant encrustations, and also diatom frustules. Standard deviation variability of grain size classes (Fig. SM1, Sabatier et al., 2008) shows four main populations of particles: $0.9-3 \mu \mathrm{m}$ (clay), 6-20 $\mu \mathrm{m}$ (silt), 40-200 $\mu \mathrm{m}$ (fine sand), 300-650 $\mu \mathrm{m}$ (coarse sand). Spectrophotometric analyses are represented in a Q7/4 diagram: the values of brightness (L_) vs 700/ 400 ratio (Debret et al., 2011), and are organized close to an end member "clayey deposit" with a more or less significant contribution of organic-rich components for a few parts of the sequence and a meaningful contribution of "altered organic matter" at the bottom of the sequence.

Principal Component Analysis on the XRF measurements (Fig. SM3 and SM4) indicates four end-members of geochemical elements that may be used to discriminate the successive sedimentary units and the variability in sedimentary facies (see below). The detrital elements group is represented by $\mathrm{Al}, \mathrm{K}, \mathrm{Ti}, \mathrm{Fe}, \mathrm{Rb}, \mathrm{Zr}$ and $\mathrm{Pb}$, the carbonate and organic matter group by $\mathrm{Ca}, \mathrm{Sr}$ and $\mathrm{Br}$, with $\mathrm{Br}$ reflecting organic matter content (e.g. Bajard et al., 2016), and the last one, $\mathrm{Si}$, is related to the silicate content. Ca and Si can be both of authigenic and allochthonous origin. Thus, the relative biogenic silica content was assessed using the XRF-derived Si:Ti ratio, Ti representing the allochthonous component (Peinerud et al., 2001). In freshwater marl lakes, the $\mathrm{Sr}$ :Ca ratio of $\mathrm{CaCO}_{3}$ precipitates in the water column and is usually controlled by biochemical fractionation and has much lower values than detrital marine carbonate from the watershed substrate that have been inorganically precipitated in other conditions. Sr-rich sediments may also reflect shallow-water sedimentation (Martín-Puertas et al., 2011). Additionally, $\mathrm{Zr}$ :Al or Ca:Al can also be used to track the grain-size variations (Wilhelm et al., 2013), where Zr corresponds to the coarse fraction while $\mathrm{Rb}$ and $\mathrm{Al}$ are respectively more influenced by silt and clay classes. Thus, increases of ratios $\mathrm{Zr}$ or Ca vs. Al represents coarser sedimentation.

According to the MS, spectrophotometric, XRF and grain size 


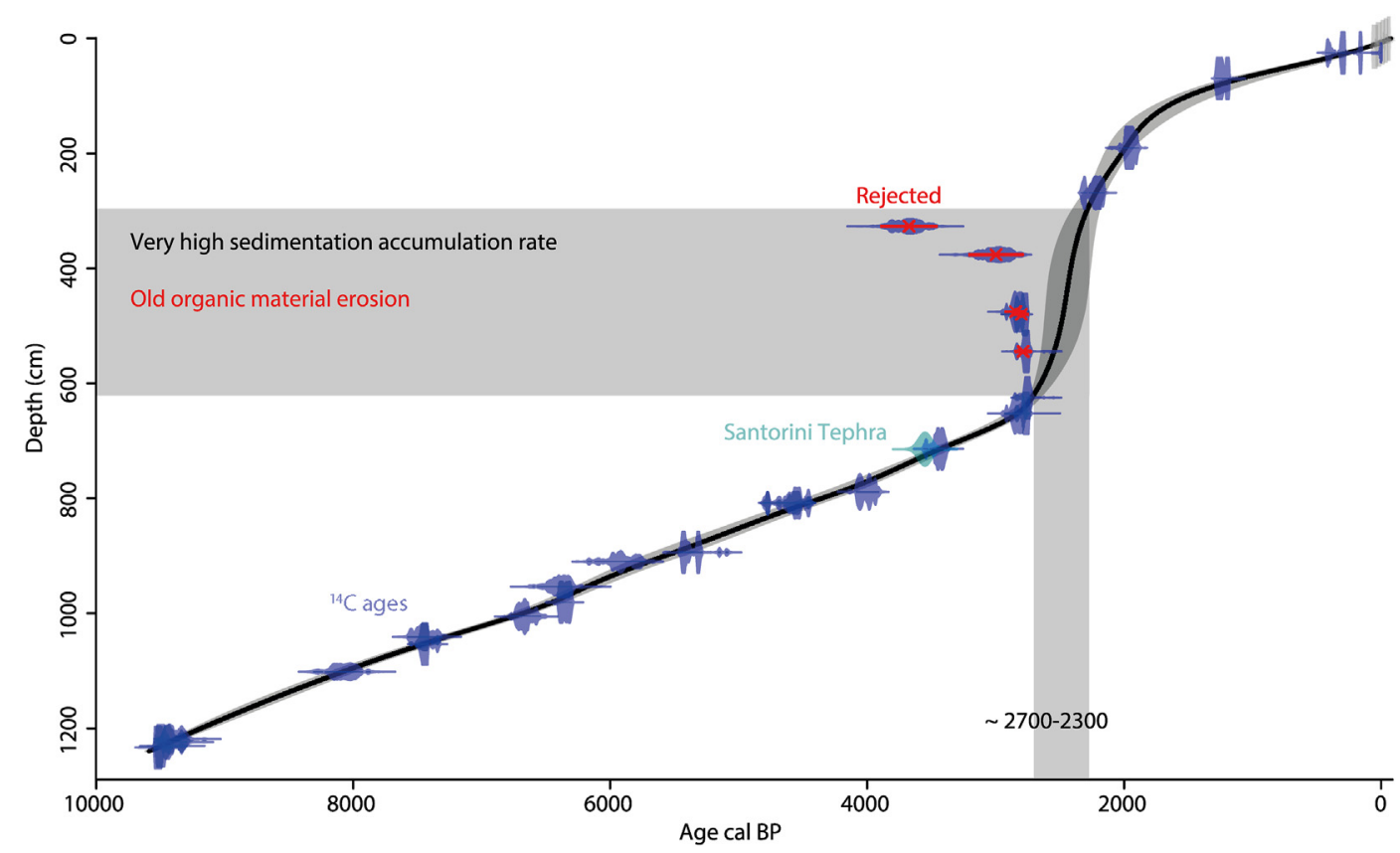

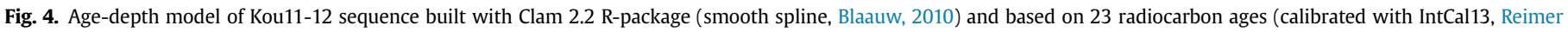
et al., 2013, Table 2), short-lived radionuclides data and the Santorini Tephra (Driessen, 2019) identified in Lake Kournas sediments.

measurements, six main sedimentary units and facies can be identified in the Lake Kournas sequence and have been named: Colluvium, Pebbles, Swamp, Lake, Flood and MWD (Fig. 3, SM2 and SM4). The "lake" sedimentary unit is subdivided into seven sedimentary sub-units to highlight periods of higher primary productivity vs. periods of higher allochthonous contribution to sedimentation.

Between the depths of 15.99 and $14.73 \mathrm{~m}$ (below the sedimentwater interface), the "Colluvium" sedimentary unit corresponds to a clayey colluvial sediment characterised by high MS signal, detrital elements, some high values of the Sr:Ca ratio and sparse decomposed organic remains (Fig. 3). There was no lake at this stage. The sedimentation then abruptly switches to an $18 \mathrm{~cm}$ thick "Pebble" layer (14.73-14.55 m depth) with centimetric carbonate pebbles within a clay matrix. The following sedimentation results in a sandy and dark sedimentary unit (14.55-14.40 m depth). Br content indicates organic-rich sedimentation that initiates a major change in the sedimentary dynamic with the presence of almost permanent water and organic matter accumulation. From $14.40 \mathrm{~m}$ depth, less detrital (MS and XRF proxies) and much more carbonate deposits reflect lacustrine type sedimentation (Fig. SM4). First stage L0 still corresponds to a shallow lake as indicated by the high Sr values, the altered organic matter content and the coarse carbonate concretions. Phase L1 begins with high MS values and an increase in fine detrital inputs that record the watershed contribution to sedimentation. But it is also accompanied by a gradual increase of the $\mathrm{Si}$ :Ti ratio that reflects a rise in lake level and primary productivity (Fig. 3). L2 corresponds to the complete lake stage with the maximum biogenic silica contribution to sedimentation (Fig. 3 and SM4). Phase L3 is well marked by a decrease of the Si:Ti ratio and a grain size distribution toward smaller grains (more silt). Phase L4 records an increase in grain size with more sand, and also by an increase in the $\mathrm{Zr}: \mathrm{Al}$ and $\mathrm{Ca}: \mathrm{Al}$ ratios, which was not the case during phase L2. During phases L5 and then L6, sedimentation is less driven by in-lake processes. There is also increase in contribution of detrital carbonates as shown by the higher Sr:Ca ratio, which attests to erosion of the surrounding soils, also confirmed by the presence of other detrital elements, e.g. Ti, Zr (Fig. SM3). Phase L6 is especially characterised by an increase in coarse grains, while biogenic silica content estimated from the $\mathrm{Si}$ :Ti ratio reaches a minimum, similar to phase LO.

Two sedimentary facies, both coarse-grained, frequently and sharply interrupt the background sedimentation described above (Figs. 2 and 3). These numerous layers result from sedimentary events of two main types: floods and mass wasting. The first type, which likely represents flood events, consists of grey-brown deposits with thicknesses ranging from 0.3 to $14.5 \mathrm{~cm}$. Seventy-six of these layers, corresponding to a total of $193.5 \mathrm{~cm}$ thickness, have been identified in sedimentary sub-units L1 to L6, due to their higher values of magnetic susceptibility and dominant fine-sand fraction. They are marked by increases in Mn that could have been precipitated in the form of Mn-oxyhydroxide (Wilhelm et al., 2016; Sabatier et al., 2017) and an increase in the detrital elements such as $\mathrm{Al}, \mathrm{Zr}$ and $\mathrm{Rb}$. XRF and grain-size analyses revealed that these sedimentary events could be graded and/or present multiple layers, as shown on Fig. 2 between 18 and $28 \mathrm{~cm}$, where two coarse brown deposits are interbedded and covered by greyish silty-clay ones. Although these deposits' elemental composition can vary slightly (Fig. SM4), and even though it is impossible to say that they are all sorted, these events can legitimately be distinguished from the background sediment in the MS and XRF data (Figs. 2 and 3). The deposits' pattern combined with the detrital composition and the grading of the event layers may reflect typical river discharge and a flood sediment signature as described in the literature (Gilli et al., 2013; Vannière et al., 2013; Wilhelm et al., 2016).

The second event type, which likely represents mass wasting, can be observed as a light grey to beige deposit (Fig. 2). These deposits show a coarser grain size, attested by the presence of the 300-650 $\mu \mathrm{m}$ fraction and a higher $\mathrm{Zr}: \mathrm{Rb}$ ratio. They are also better sorted with $75 \%$ of grains coarser than $40 \mu \mathrm{m}$, depleted in detrital component (e.g. low values of $\mathrm{MS}, \mathrm{Al}, \mathrm{Zr}$ and $\mathrm{Rb}$ ) but enriched in $\mathrm{Sr}$ in particular (Fig. 2 and SM4). Binocular observations show numerous carbonate concretions typical of the littoral platforms that belt the lake. Thus, these light grey deposits are of lacustrine 
origin and may correspond to subaquatic mass-movements and so results from the carbonate platform material reworking and the mixing of lacustrine sediments from the slopes and the shores of the lake (Vannière et al., 2013). Five Mass Wasting Deposits (MWD), ranging between 1.0 and $6.5 \mathrm{~cm}$ thickness, of this second type of event layer, have been identified along the entire sequence for a cumulative thickness of $16.6 \mathrm{~cm}$.

\subsubsection{Tephra geochemistry}

Only one sample from Lake Kournas contained glass shards (sample Kou11 A3-1 71, Depth MC $845 \mathrm{~cm}$ ), which are of rhyolitic composition (Tab. SM1, Fig. SM6) and belong to the high-K calcalkaline series (Fig. SM6b). Likely Holocene sources for tephra in the study area are Aegean and Turkish volcanos (Sulpizio et al., 2013). Considering the tephra layer's rhyolitic composition, the Gölcük and Kula volcanoes in central-western Turkey can be excluded because their alkaline products never reached the rhyolitic field (Elitok et al., 2019). Nore are the explosive products from Cappadocian volcanoes a match; they are too evolved with $\mathrm{SiO} 2$ in excess of 75 wt\% (Druitt et al., 1995; Develle et al., 2009; Hamann et al., 2010; Fig. SM6a). Thus, having excluded most of the Turkish sources, the high-K calc-alkaline character of the Kournas tephra indicates an origin within the Aegean volcanic arc. Santorini (Thera) is the most prominent volcano in the Aegean arc and has erupted in a big way at least 12 times since the mid-Pleistocene, c. 300,000 years ago (; Druitt et al., 1989, Druitt et al., 1989, 1999; Wulf et al., 2020). The identification of Santorini as the source of the Kournas tephra is confirmed by our geochemical data, which shows a strong correspondence in major elements (Tab SM1, Fig. SM6), and is comparable with other published distal data (Sulpizio et al., 2013).

\subsubsection{Chrono-stratigraphy and sediment accumulation rate}

To build the age-depth model, flood deposits and MWD (see 4.1.1. above) were removed from the chrono-stratigraphy because their instantaneous deposition is inconsistant with the long-term background sedimentation.

Thanks to the serac R package (Bruel and Sabatier, 2020) we applied the CFCS (Constant Flux Constant Sedimentation) model to the ${ }^{210} \mathrm{~Pb}_{\text {ex }}$ activities, which estimate a mean sedimentation accumulation rate of $1.621 \pm 0.102 \mathrm{~mm} / \mathrm{yr}\left(\mathrm{r}^{2}=0.9439\right.$, Fig. SM5). ${ }^{137} \mathrm{Cs}$ activity in the upper $25 \mathrm{~cm}$ of the core shows a well-defined peak at 70-75 mm depth (Fig. SM5), which is interpreted as the 1963 maximum atmospheric nuclear weapons tests in the Northern Hemisphere (Appleby, 2001). The results from radiocarbon and short-lived radionuclides analyses were combined to produce an age-depth model showing that the upper $14.5 \mathrm{~m}$ (Figs. 3), $12.4 \mathrm{~m}$, after the removal of the flood deposits and MWD, records the last 9600 years (Table 1, Fig. 4).

Five radiocarbon measurements were excluded from the agedepth model because their dates were reveresed (Table 1). This suggests that the samples producing the reversed dates may have been from reworked, older organic material deposited during a period of rapid sedimentation (9 $\mathrm{mm}$ per year) when the lake platform/shelf and/or surrounding soils were strongly eroded (Figs. 3 and 4). Except for this particular period of rapid accumulation between 2700 and 2300 cal BP, the mean sedimentation accumulation rate is on average $0.8 \mathrm{~mm}$ per year for the bottom part of the core, and $0.6 \mathrm{~mm}$ per year for the upper part.

The radiocarbon age measured from the wood sampled $1 \mathrm{~cm}$ above the tephra layer is $3460 \pm 90$ cal BP. This date is remarkably close to that proposed for the Minoan eruption of the Santorini (Thera) volcano by Driessen (2019), c. $3500 \pm 50$ cal BP.

The estimated ages of the main sedimentary units are: the Colluvium and Pebble units are older than 9600 cal BP, the Swamp unit sedimented between 9600 and 9540 cal BP, the first lake phase
L0 spans between 9450 and 8500 cal BP, L1 lasts about 2000 years between 8500 and $6500 \mathrm{cal} \mathrm{BP}, \mathrm{L} 2$ is the longest phase between 6500 and 2700 cal BP, the high sedimentation accumulation rate phase L3 occurred between 2700 and 2300 cal BP, L4 and L5 end respectively around 2000 and 1700 cal BP, L6 goes up to the present day.

\subsubsection{Sedimentary event chrono-stratigraphy}

Analysis of flood event frequencies indicates three periods with more than one flood deposit per century: 8100 to 7700 cal BP, 5700 to $5300 \mathrm{cal} \mathrm{BP}$ and 4600 to 2000 cal BP (Fig. 5). All periods of increased flood-deposit frequency are also well marked at their start by significantly thicker deposits (more than $7 \mathrm{~cm}$ thick) that might indicate the erosion of a larger quantity of material in the watershed and/or more intense event (Giguet-Covex et al., 2012; Wilhelm et al., 2013). Flood deposits are thicker than the mean ( $2 \mathrm{~cm}$ thick) between 8400 and $8150 \mathrm{cal} \mathrm{BP}, 6600$ and $5700 \mathrm{cal} \mathrm{BP}$, 3900 and $450 \mathrm{cal}$ BP. No flood deposits have been recorded between 9600 and $8500 \mathrm{cal} \mathrm{BP}, 7300$ and $6600 \mathrm{cal} \mathrm{BP}$ or $450 \mathrm{cal} \mathrm{BP}$ and the present-day.

MWD-type deposits are much less frequent than flood ones; only five are recorded and they occurred within a relatively short period: 3900 to 1300 cal $\mathrm{BP}(3860 \pm 85,3435 \pm 60,2390 \pm 140$, $1980 \pm 105,1280 \pm 140$ BP; Fig. 5). The thickest MWD deposit $(6.5 \mathrm{~cm})$ is associated with the tephra record, the glass shards having been detected within the layer that caps the MWD.

\subsection{Biostratigraphy}

\subsubsection{Pollen}

Four main local pollen zones (PZ, Fig. 6 for selected taxa and SM7a-7b for the complete pollen diagram) were identified by means of stratigraphically constrained cluster analysis. During PZ1 ( 9600-8500 cal BP), the arboreal pollen (AP) curve, which was around $35 \%$ in the oldest sample, rapidly increases up to $70-80 \%$. deciduous-type pollen increases throughout the period and dominates the assemblages. Mediterranean taxa, such as Quercus ilex/ Q. coccifera and Pistacia are already present, as is a tiny blip of Olea in mid Zone. The Vitis percentages are important, around $10 \%$ of the TLP. Herbaceous taxa that represent $60 \%$ in the first samples stabilize around 30\% from 9500 cal BP onward. Poaceae do not exceed $10 \%$ of the TLP, and the herb diversity is already significant. Cerealiatype pollen are present from the first sample, with grains as big as $45 \mu \mathrm{m}$. We notice occurrences or continuous presence of weeds and ruderals such as Centaurea cyanus-type, Plantago lanceolata-type, Rumex acetosa-type, Mercurialis or Urtica.

An abrupt and significant reversal characterises the transition between PZ1 and PZ2 ( 8500-5900 cal BP) in the Quercus proportions: $Q$. deciduous-type fall from $60 \%$ to $15 \%$ of the TLP while Quercus ilex/Q. coccifera rises from less than $10 \%-50 \%$. Taxa that where absent or that showed only sporadic and tiny occurences during Zone 1, appear and/or increase during the subzone 2a ( 8500-7000 cal BP), namely Fraxinus ornus and the sclerophyllous taxa related to maquis species such Erica and Phillyrea, together with Olea after 7500 cal BP. During subzone 2 b, Phillyrea and then Q. ilex/Q. coccifera decrease. Herbaceous taxa assemblages do not significantly change except the aquatics with a Myriophyllum curve in the first half of subzone 2a ( 88,500 - 7500 cal BP). Between 7500 and $6700 \mathrm{cal}$ BP the temporary disappearance of some herb's taxa, such as Senecio sp. Lotus-type, Ranunculus or Rhinanthus/ Veronica is noticeable.

The PZ3 (5900-2400 cal BP) is characterised by an important increase of Olea pollen, which changes from 3\% to $22 \%$ after 6000 cal BP, while $Q$. ilex/Q. coccifera decreases accordingly. A rise of Rosa- and Rubus-type occur during subzone $3 \mathrm{~b}$, substituted by 


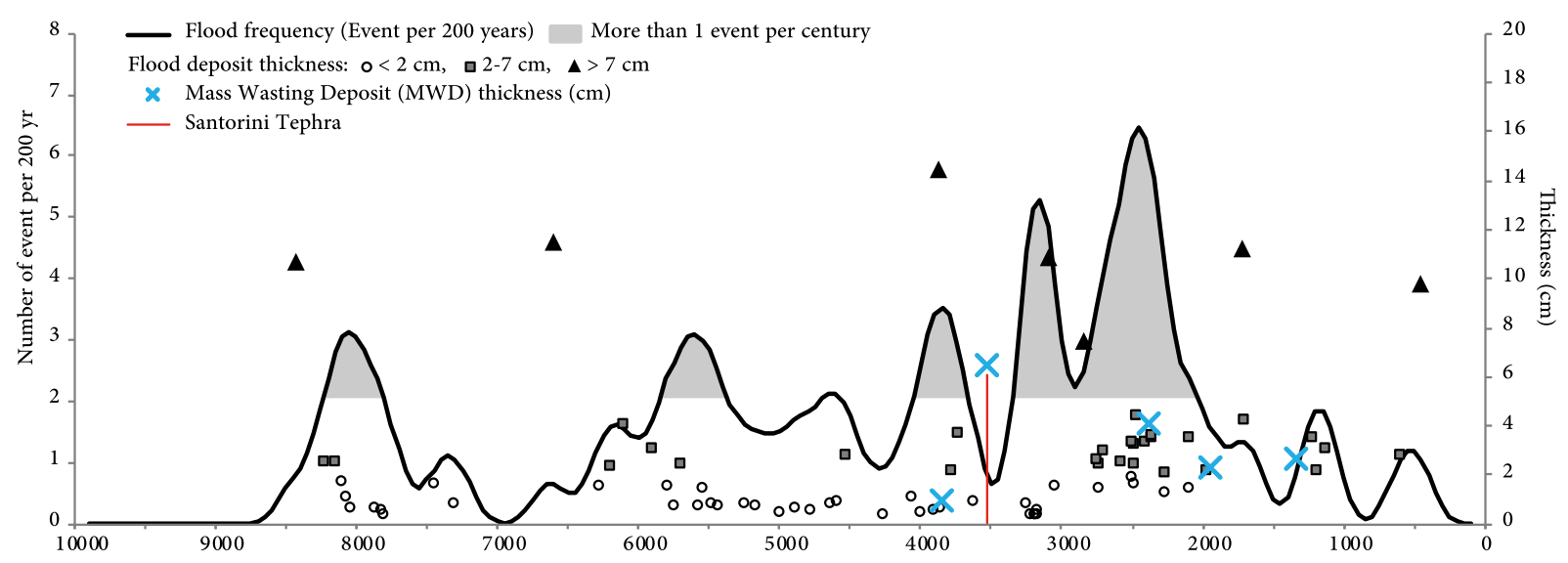

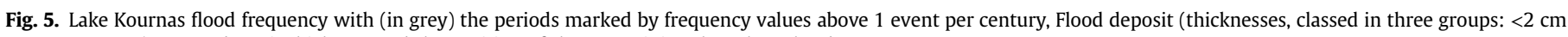
$2-7 \mathrm{~cm},>7 \mathrm{~cm}$ ), MWD deposit thickness and the position of the Santorini tephra glass shards.

Sarcopoterium spinosum-type and Phlomis-type in subzones $3 \mathrm{c}$ and $3 \mathrm{~d}$. An important peak in $Q$. deciduous-type is localised around $3700-3500$ years BP at the beginning of zone 3c. During subzone $3 c$, Ulmus/Zelkova pollen became more abundant. Finally, the percentages of Olea are lower in subzone $3 \mathrm{~d}$. The main change in herbaceous taxa assemblages is the sustained decrease of Galeopsis-type, Brassicaceae, Ranunculaceae and Rhinanthus/Veronica at the end of subzone $3 \mathrm{~b}$.

PZ4 (2400 cal BP to the present day) begins with a new huge and rapid increase in the proportion of Olea, which oscillates between $20 \%$ and $35 \%$ of the TLP during the entire subzone $4 \mathrm{a}$ (2400 1400 cal BP). Its decrease during subzone $4 \mathrm{~b}$ runs alongside a higher amount of $Q$. ilex/Q. coccifera pollen that decreases again after $1000 \mathrm{cal}$ BP. Subzone $4 \mathrm{c}$ is characterised by a reduced presence of both evergreen and deciduous Quercus pollen and the increasing presence of introduced and/or potentially cultivated trees and shrubs, such as Juglans, Castanea, Vitis or Styrax. An increase in Q. ilex $/ Q$. coccifera, Olea, and to a lesser extent Cupressaceae is observed in the most recent samples. A change in herbaceous taxa assemblages is most visible in subzone $4 \mathrm{c}$ where there is an increase in Poaceae, Plantago lanceolata-type, Rumex acetosa-type, Artemisia and the Cichorioideae, together with an increase in Myriophyllum, Alisma and the regular occurrence of Juncus.

\subsubsection{Pollen biodiversity}

Globally, both richness and evenness trends agree, illustrated by evenness-detrended palynological richness (DE-PRI) that mirror richness (Fig. SM8). The global trend of Pollen Richness (PRI) and DE-PRI are in good accordance all through the sequence with one exception, the first part of the sequence between 9600 and $\sim 8500$ cal BP. This discrepancy indicates that pollen richness is affected by unevenness, caused by a few dominant taxa, especially here $Q$. deciduous-type (peaking at 8500 cal BP with $\mathrm{PIE}<0.6$ ). Thereafter, species richness estimates (PRI) seem to be unaffected by evenness biases, allowing PRI be used as a proxy for plant biodiversity change (Colombaroli and Tinner, 2013, Fig. 7). From 8750 cal BP onward, both PRI and DE-PRI increase, reaching a first maximum around $8000 \mathrm{cal} \mathrm{BP}$. Between 8000 and $7000 \mathrm{cal}$ BP PRI declines; but, it rises again and stabilizes at a high level for about three millennia between ca. 6000 and 3000 cal BP, which corresponds roughly to pollen zones PZ3a to PZ3c. Between 3000 and 2500 cal BP, the pollen richness index declines (PZ3c). A lower level of pollen richness is recorded from ca. 2300 to $1250 \mathrm{cal} \mathrm{BP}$ during PZ4a. Between 1250 and 500 cal BP PRI values steadily increase. The last 500 years are characterised by a high level of pollen richness despite a slight decline. The last 60 years (PZ4d) initiates a decreasing trend anew.

\subsubsection{Fungal remains}

All the identified fungal remains are both saprophytic and coprophilous taxa, except Glomus (HdV-207), an arbuscular mycorrhizal fungus found in association with the roots of various plants, which is often used as erosion indicator (Kołaczek et al., 2013). Their assemblages have been statistically divided into three major fungal zones (FZ, Fig. SM9). During the first zone FZ1 (9600-8500 cal BP) abundance and diversity of identified fungal remains are low. However, spores of obligate coprophilous fungi, namely, Sporormiella, Sordaria and Podospora (Baker et al., 2013) are present in the older samples. The transition between FZ1 and FZ2 (8500 - 3500 cal BP) displays an increase in both quantity and diversity of fungal remains. Sporormiella is now already present, and Sordaria and Xylariaceae/Coniochaetaceae spores are regular. Only the short-lasting subzone $2 \mathrm{~b}$, between 3700 and $3500 \mathrm{cal} \mathrm{BP}$, is free of fungal remains. FZ3 ( 3500 to present day) is characterised by an overall increase of all the taxa previously registered. The phenomenon reaches a maximum between 2500 and 1950 cal BP (subzone $3 \mathrm{~b}$ ), together with the appearance of new taxa such as Pleospora and Triposporium elegans. After 1500 cal BP, all taxa sharply decrease during zone $3 \mathrm{c}$ and even more during subzone $3 \mathrm{~d}$. Only Sporormiella is observed throughout the most recent samples.

\subsubsection{Algae remains}

Algal remains were regularly present on pollen slides, even abundant in some samples. Despite the fact that a recent study demonstrates that algal remains on pollen slides are not a direct reflection of biomass (Stivrins et al., 2018), in the Kournas sequence, four main algal remains zones (AZ) were determined (Fig. SM9). During the earliest phase, AZ1a (9600 - 8400 cal BP), the green algae Botryococcus sp. and Tetraedron minimum are regularly present but in low quantities. After 8800 cal BP, Botryococcus increases sharply, soon followed by sharp peaks in Pediastrum boryanum and Tetraedon minimum, and small amounts of Volvocaceae and Spirogyra sp. During the subzone AZ1b (8400 - 7500 cal BP) all the previous taxa decrease significantly but continue to be present until 8000 cal BP for Pediastrum and 7500 cal BP for Tetraedron. Low amounts of algal remains characterise AZ2 (7500-3000 cal BP). From 7500 to 5400 cal BP algal remains are almost absent, and after 5400 cal BP only Botryococcus sp. are present. Around 3200 cal BP Scenedesmus-type appears for the first time as a sharp peak. A growing amount and diversity of algal remains characterise zone 


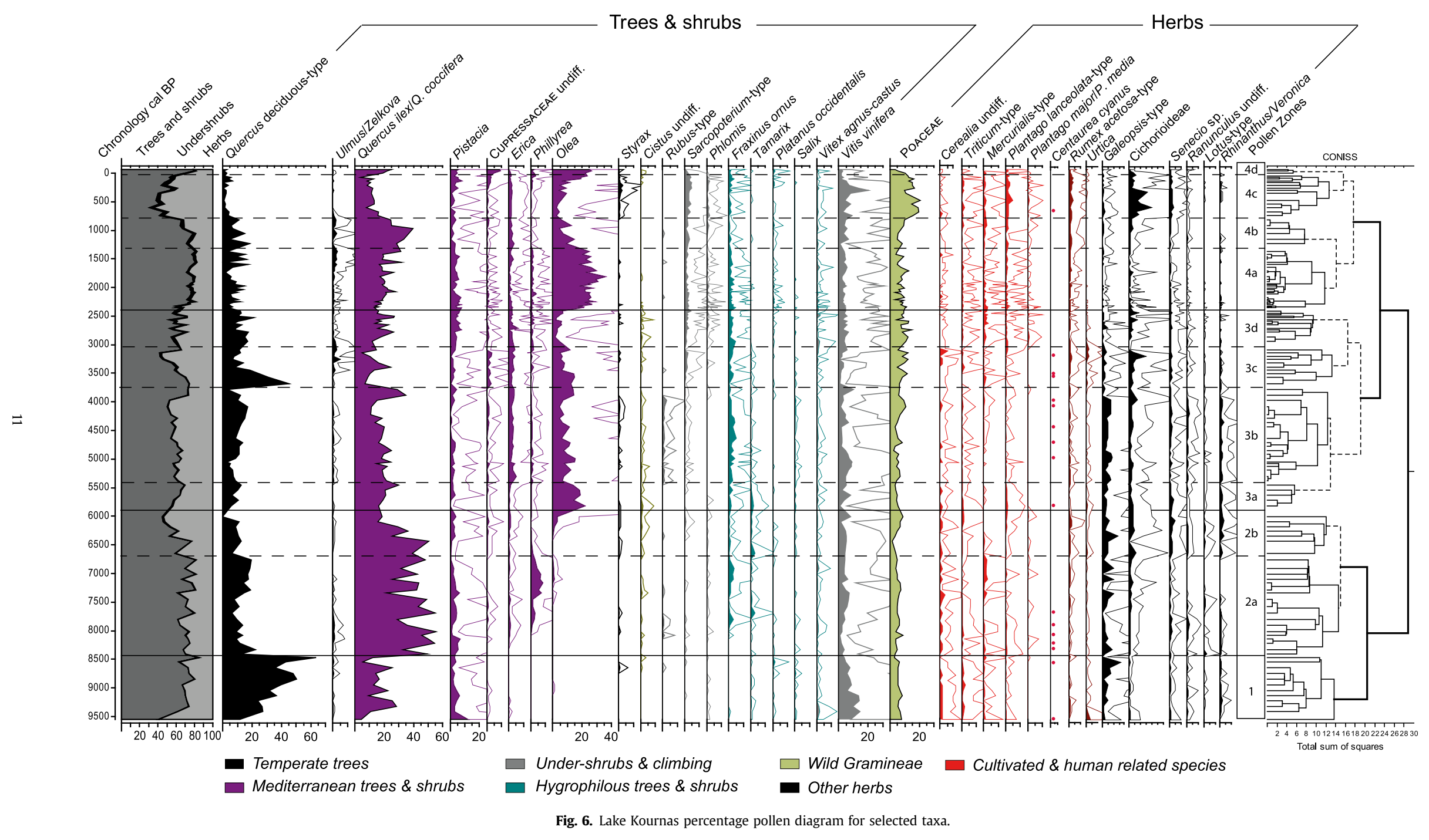


AZ3 (3000 - 1900 cal BP). Dinocysts, probably Peridinium-type (McCarthy et al., 2018), Anabaena sp. and Volvocaceae are the main taxa, together with the previously present Botryococcus. During subzone 4a (1700-1200 cal BP), Dinocysts sharply decline following an increase in Volvocaceae. All algal remains decrease in subzone $4 \mathrm{~b}$, and only some Botryococcus remain in the upper part of the core.

\subsubsection{Microscopic charcoal}

Four main zones can be visually distinguished in our microscopic charcoal record from the Lake Kournas (Fig. SM10). CZ1, 9600 to 7000 cal BP, shows high charcoal influx values briefly interrupted by a few short periods with lower signals. The highest peaks attest to numerous fire events and/or quantity of biomass burned in the lake surroundings. During CZ2, 7000 to $6100 \mathrm{cal}$ BP, the sedimentary charcoal content is very low, meaning that few fires occurred during these nine centuries in the area except for a single slight charcoal increase at ca. 6600 cal BP that may show increased regional fire occurrences. CZ3 is the longest zone, 6100 to $1900 \mathrm{cal}$ $\mathrm{BP}$, and includes five successive and pluri-centennial episodes of microscopic charcoal inputs into the lake, each separated from the other by a few centuries of very low charcoal signals. During CZ4, 1900 cal BP to the present day, the charcoal signal declines to the lowest values in the sequence - nearly zero - apart from a short phase of very slight increase between ca.1100 and $700 \mathrm{cal} \mathrm{BP}$. This fourth zone attests to a near-absence of fire in the region of Lake Kournas.

\subsubsection{Diatoms}

Diatom preservation was generally good, although in 9 out of the 30 samples, counts were only 100 valves. A total of 36 diatom taxa were identified, and the stratigraphic diagram (Fig. SM11) shows those taxa present at $>2 \%$ relative abundance. The diatoms are dominated by two centric genera, that are planktonic or facultative planktonic in life form, with benthic/periphytic taxa relatively uncommon. These observations suggest that relatively deep-water conditions prevailed through most of the lake record. Our results can be compared against those of John and EconomouAmilli $(1990,1991)$ who studied diatom plankton living in the lake today. Two species of Cyclotella dominate their results, one of which, $C$. cretica, was identified as a new endemic species, and which is likely to equate to $C$. ocellata in our analyses (SEM analysis would be required to differentiate them). C. cretica and C. ocellata appear to have similar ecological requirements, and taxonomic differentiation between them is therefore unlikely to substantially alter our palaeolimnological reconstruction, including the former lake salinity.

Four major downcore assemblage zones can be recognized (DZ). Zone DZ1 (9600- 8500 cal BP) is characterised by Cyclotella ocellata/cretica, Cyclotella meneghiniana and Cyclotella distinguenda along with the araphid diatom Fragilaria brevistriata. Freshwater taxa account for around 59\% of total diatoms in this zone. In DZ2 ( 8500-7700 cal BP), Actinocyclus normanii abruptly increases, reaching a relative abundance of $\sim 30 \%$, and $S$. tabulata (araphid planktonic) also increases to a maximum of $\sim 41 \%$. A. normanii is an indicator of a saline and/or marine environment, and diatominferred electrical conductivity (DI-EC) increases markedly in this zone to $>8000 \mu \mathrm{S} / \mathrm{cm}^{-1}$. In DZ3 $(\sim 7700-1500-1100$ cal BP), the longest zone, $C$. ocellata/cretica and $C$. distinguenda dominate, and DI-EC decreases to $<1000 \mu \mathrm{S} / \mathrm{cm}$; this is the period of lowest salinity in the entire Holocene record. DZ4 ( 1500-1100 cal BP to present day) covers the last millennium and is associated with an increase in C. meneghiniana, which drives the DI-EC above $1000 \mu \mathrm{S} /$ $\mathrm{cm}$ except in the uppermost sample.

\section{Discussion}

\subsection{Kournas' landscape history}

Some 10,000 years ago, the Kournas site was like a doline, at least seasonally dry. Around $9600 \mathrm{cal}$ BP, after a mass movement of pebbles, the sinkhole became a swamp. Quickly, probably from $9450 \mathrm{cal} \mathrm{BP}$, the continuous sedimentation of carbonate marl, the dominance of planktonic diatoms, and taxa preferring low salinities indicate that Lake Kournas became a freshwater body progressively moving from a shallow to a relatively deep basin over the last $\sim 8500$ years.

\subsubsection{An Early Neolithic occupation of the oak forest (9600-8500 cal $B P)$ ?}

Before 8500 cal BP, a mixed forest of deciduous and evergreen oaks, with a majority of deciduous oak, covered the shallow lake's surroundings (Fig. 7). A few fire episodes occurred, but the woodland cover was apparently resilient and stable for about 1000 years. The first millennium of the Kournas record corresponds to the transition from the Mesolithic to Crete's Neolithic. Very little is known about the neolithization of western Crete. The earliest phase of the Early Neolithic is, at present, only known at the archaeological site of Knossos in north-central Crete. Research on this site has revealed a well-preserved stratigraphy of a pre-Minoan occupation (Efstratiou et al., 2013) with an initial phase dated between 9000 and 8550 cal BP ( 7050-6550 BCE, Facorellis and Maniatis, 2013; Douka et al., 2017). This Pre-Pottery Neolithic (PPN) phase most likely resulted from visits by Neolithic people from Anatolia, who brought with them a "package" of wild and cultivated plants and feral and domesticated animals (Efstratiou, 2013; Horwitz, 2013; Nowicki, 2014).

The Kournas record may document further or contribute to the debate about the early dating of the Neolithic onset in Crete. Indeed, the oldest samples containing pollen ( 9600 cal BP) include large pollen grains (grains with a size up to $50 \mu \mathrm{m}$ and pores up to $10 \mu \mathrm{m}$ ) that fit with Triticum-type (Beug, 2004). Triticum-type pollen also includes some wild Poaceae species and therefore the local presence of wild Poaceae producing large pollen grains cannot be excluded. However, Triticum-type pollen's occurrence does not significantly change over the whole sequence, which would mean that the introduction of crop cultivation is not visible in the Kournas pollen sequence (Fig. 6 and SM7b). Weed and ruderal taxa such as Plantago lanceolata-type, Urtica and Rumex acetosa-type are already present in the palynofacies between 9600 and 8500 cal. BP (Fig. SM7b). In addition, obligate dung fungal spores of Sporormiella, Sordaria and/or Podospora (Baker et al., 2013) are present in the three oldest samples (Fig. 7 and SM9). Of course, the earliest fungal spore signal might represent the presence of wild animals in the area. For example, the now-extinct genus of deer (Candiacervus) found in cave sites on Crete and almost certainly the subject of cave art representations in Asphendou Cave (Strasser et al., 2018). Other deer species are also found in faunal assemblages that post-date this period (Moody, 2012). Pollen and fungal indicators are not sufficient on their own to attest to the presence of agro-pastoral activities as early as 9600 cal BP ( 7650 BCE), which is five centuries before the oldest settlement at Knossos. However, considering that the Kournas basin at that time might have been an attractive zone for humans and animals because freshwater was one of the main concerns of the first settlers (Nowicki, 2014), and knowing from archaeology that the first waves of farmers spread to Cyprus at least one millennium before $(10,600$ years ago, Vigne et al., 2012), the hypothesis of a human presence around Kournas in the mid-eighth millennium BCE is worth considering. 


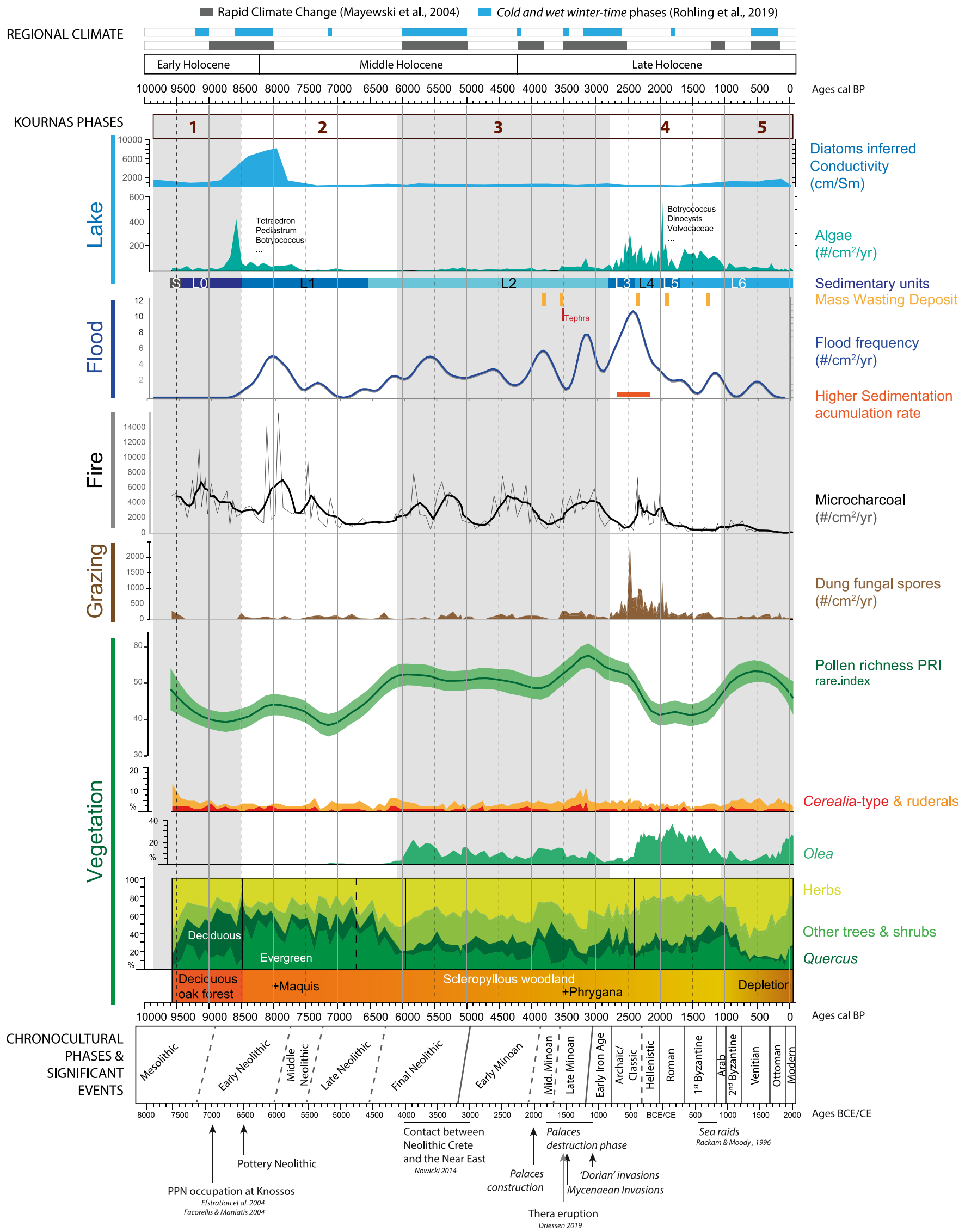


5.1.2. Sclerophyllous woodland and Neolithic slash and burn (85006100 cal BP)

The lake sedimentary dynamics (phase L1, Fig. 3, SM2 and SM4) and all bio-indicators of the lacustrine setting show a major change around 8500 years ago, with the establishment of a true deepwater body (Fig. 7). The increase of algal remains together with the major change in diatom assemblages attest to this evolution, with the diatoms indicating a brief period when the lake was saline before becoming freshwater and deep (Figs. 3 and 7). At this time, there were also rapid and long-lasting changes in the surrounding vegetation, with a noticeable expansion of evergreen oak in the woodland at the expense of deciduous oak. This vegetation shift took place during a period marked by fewer fire episodes.

For two millennia, from 8500 to $6500 \mathrm{BP}$, a relatively stable vegetation cover prevailed. Mediterranean woodland and maquis dominated the surrounding landscape of the lake with a few short periods of maquis species increase, especially Erica and Phillyrea (Fig. 6), while a few high amplitude charcoal peaks attest to fire episodes in the vicinity of the lake, notably around 8100, 7900, 7500 and 7150 cal BP. The evergreen oak curve is irregular and the localised decreases are concomitant with slight increases in pollen richness, especially between 8000 and 7000 cal BP (Fig. 7), i.e. when fire disturbed the ecosystem, and likely promoted biodiversity (Lestienne et al., 2020).

The flood record starts from 8400 cal BP with a first thick flood deposit, and the frequency of events then increases to more than one event per century between 8300 and 7800 cal BP. Floods might have been driven by increases in soil erodibility associated with land-cover changes due to the advent of grazing pressure (e.g. Giguet-Covex et al., 2011; Vannière et al., 2013; Bajard et al., 2020) and/or climate oscillations around the 8.2 cal BP event (see part 5.2.5; Pross et al., 2009; Daley et al., 2011; Kouli et al., 2012; Dean et al., 2015). Indeed, the first thick flood layer of the record follows the reappearance of the dung fungal spores and their longlasting presence in the record. This period corresponds to a major cultural change in Crete, namely the onset of the Pottery Neolithic (Nowicki, 2014) with an Early Neolithic open-air settlement attested at Knossos around 8500 cal BP ( 6550 BCE) (Efstratiou, 2013). While we have little direct evidence for Neolithic activity in the Lake Kournas catchment, the presence of well-known cave sites in this region, such as Gerani Cave, certainly suggest that Neolithic peoples were present. Tomkins (2008) argues for an expansion in settlement during the pre-Final and Final Neolithic. The higher areas beyond the immediate catchment of lake Kournas may well have seen activity during these periods. Around Lake Kournas, the best clue to agro-pastoral activities is the synchronous increase in ruderal taxa and crop pollen along with the dung fungal spores. Thus, the fire episodes might reflect a controlled use of fire for land management by the Early Neolithic population (Vannière et al., 2016; Marriner et al., 2019). Although the flood episodes might represent the first human impact on soil erosion, they are also contemporary with period of climate change (Mayewski et al., 2004) (see part 5.2.5.).

Olea pollen, which heretofore was very scarce, is regularly identified after 7500 cal BP ( 5550 BCE) (Fig. SM7a). The question about Olea as a native species in Crete or as an imported species by mean of overseas contact is still in debate (Bottema and Sarpaki, 2003; Langgut et al., 2019). On Crete, the absence or the lateHolocene appearance of olive wood or charcoal in archaeological contexts contrasts with the Cypriot and the Levantine data (Carrión et al., 2010; Badal and Ntinou, 2013). According to pollen records (Langgut et al., 2019) and genetic data (Besnard et al., 2018), Northern Greece is included in the oleaster refugia area during the Last Glaciation; but the situation in southern Greece is less clear. At Kournas, wild olive trees developing in the sclerophyllous vegetation between 7500 and 6600 cal BP might be a plausible interpretation of the pollen record, whether they are the result of a natural process or an introduction by early settlers.

The end of this period, i.e. between 6600 and 6100 cal BP (Fig. 7), displays a decline in woody land cover, driven by the gradual fall of evergreen oak pollen, and an increase in pollen richness. A few flood deposits reappear, which might be related to regional climate change marked by wetter winters (Rohling et al., 2019) but may also be the consequence of changes in vegetation cover and soil erodibility, that also prompted lake conditions to become more productive (Si:Ti increases, Fig. 3 and SM4).

\subsubsection{The first phase of olive exploitation, Final Neolithic through Early Iron Age (6100-2800 cal BP)}

From 6100 cal BP $(4150 \mathrm{BCE})$, the key environmental changes in the surroundings of Lake Kournas correlate with a gradual decrease in Mediterranean woodland and maquis, which were replaced by crops and pastures (Figs. 6 and 7). The amplitude of charcoal peaks is quite similar throughout this period and may correspond to a regular fire regime driven by the same forces. A long-lasting increase of Olea pollen occurred around $6100 \mathrm{cal} \mathrm{BP}$ and may reflect the beginning of olive cultivation during the Final Neolithic. Olea was almost absent in the oldest periods and its rapid increase at this time does not correspond to an increase in any other woodland or maquis species (see part 5.1.2). The olive pollen profile is comparable to the those at Delphinos a few kilometres away (Bottema and Sarpaki, 2003), at Tersana on the Akrotiri peninsula (Moody et al., 1996), and in two other recent pollen records from central and eastern Crete that suggest the existence of olive exploitation and/or cultivation on the island from the Final Neolithic to the Early Minoan at Palaikastro (Cañellas-Boltà et al., 2018), and during the Early Minoan near the palatial site of Phaistos (Ghilardi et al., 2018). Archaeobotanical evidence in the form of olive oil residue from Final Neolithic pots at Gerani Cave (Martlew and MARTLEW, 1999), demonstrates that processing olives into oil was known by this time.

At Lake Kournas, the establishment of olive cultivation was part of the landscape's environmental and cultural evolution during the transition from the 5th to the 4th millennium BCE (around 6000 $\mathrm{BP}$ ); changes that were accompanied by increasing fire and high level of pollen richness (Fig. 7). Fire may have been used as a tool to clear vegetation, and biodiversity may be enhanced by humanrelated disturbances or introduced plants. Simultaneously, flood frequency increased, reaching more than one event per century between 5700 and 5400 cal BP (first half of the 4th millennium $\mathrm{BCE}$ ). Thereafter, during the 4th and 3rd millennia BCE, the flood regime oscillated, slightly below the centennial regime value, and the deposits remain in the majority thin, perhaps because of the relative stability of soils.

In Crete, 5000 years ago, the onset of the Bronze Age corresponds to the rise of the Minoan culture, one of the most famous ancient civilisations in the Mediterranean. However, the Minoan period onset does not display any major change at Kournas. During the Early Minoan period (from $\sim 5000$ cal BP), land use was relatively stable. Pollen and spore records indicate olive cultivation,

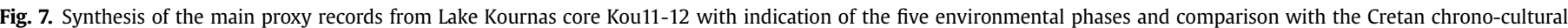

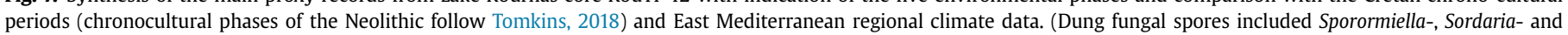
Podospora sp.) 
crops and animal husbandry, but no or a few fire during the first 500 years. Then, from ca. 4600 to 4000 BP, sharp charcoal peaks clearly attest to fire events near the lake. The main features of the woodland (Mediterranean trees and maquis) and herbaceous taxa remained stable. Olive probably continued to be cultivated near Lake Kournas. Nevertheless, any temporary abandonment of olive cultivation would not result in Olea pollen's disappearance, as olive trees form part of the Mediterranean vegetation assemblage. The large and quite obvious variations in sedimentary charcoal content reflect an irregular use of fire and possible land-use changes over the period. However, there is no evidence of any impact on soils that may have been attested by some change in sedimentary dynamics over this long period.

An increase in woodland characterised the Middle Minoan period (from $\sim 4000$ cal BP), first dominated by evergreen oak and then by deciduous oak. Olea pollen percentages also increased while Cerealia-type pollen, dung fungal spores and charcoals remained low (Fig. 7). These may indicate a decline in local agropastoral activity, with the possible exception of olive cultivation. It is also possible that the Olea pollen came from trees growing naturally in the Mediterranean woodland. 'Between 4000 and 3600 cal BP (2050-1650 BCE) flood frequencies increased to more than one event per century.

Late Minoan period ( 3700 cal BP to 3100 cal BP), is said to have been affected by a succession of disturbances that led to the end of the Minoan culture in Crete. They include natural hazards - such as earthquakes and volcanic activity, the most famous being the Thera/Santorini eruption some 3500 years ago, i.e. in the mid-16th century BCE (Driessen, 2019) - and socio-economic instability marked by internal crisis, sea raids and palace destructions (Knapp and Manning, 2016). In the Lake Kournas record, this period is characterised by a MWD in the lake basin, Santorini Tephra, and an increase in charcoal accumulation. Simultaneously, a decrease of olive pollen grains favouring other crops and pastoral indicators (Triticum-type, Rumex, Urtica, Fig. SM7b or spores of coprophilous fungi, Fig. SM9) indicating a change in land use that favoured biodiversity. Woodland decreased, while no flood layers are registered.

All indicators suggest an abandonment of agro-pastoral activities between 3100 and 2800 cal BP (1150-850 BCE), i.e. during the Early Iron Age (Fig. 7). The area of oak woodlands increased, Olea declined to its lowest levels since 6000 cal BP, while grazing (dung fungal spores) and fires (charcoal) decreased. Such a discontinuity in human activities after the Minoan Civilisation's demise was also documented by palaeoenvironmental studies near Phaistos (Ghilardi et al., 2018).

\subsubsection{The Greek, Hellenistic, Roman and early Byzantine periods (2800-1150 cal BP)}

The Archaic Greek period saw a major shift in all components of the anthropo-system and in the lake dynamics, which had been set up during the previous millennia.

As a first step, a major fifteen fold increase in the sediment accumulation rate (Figs. 3, 4 and 7, sedimentary unit L3), led to a rapid accumulation of mainly silt-sized material in the lake basin: about $3 \mathrm{~m}$ in no more than 500 years. This phase occurred between 2800 and 2400-2300 cal BP (850-450-350 BCE) and corresponds to the Archaic/Classical periods. Part-way through this phase, algal productivity increased in quantity and diversity. The dominant taxa - Botryococcus, Dinocysts of Peridinium-type and Volvocaceae suggest lake eutrophication (Jankovská and Komárek, 2000; McCarthy and Krueger, 2013) caused by an increase in nutrient input into the lake. At the same time, sedimentation was interrupted by numerous flood deposits that reflect an increase in the event frequency up to 5-6 floods per century, i.e. more than once every 20 years. The fire signal remains low, and there are only a few variations are recorded in pollen assemblages which are dominated by sclerophyllous woody taxa but with low olive representation. Pollen biodiversity is down slightly. In contrast, dung fungal spores steadily increase, in quantity (Fig. 7) and diversity (Fig. SM9), possibly indicating a new phase of pastoralism in the watershed, possibly in the way herding was done. But we can't define these herding types futher. The reversal of radiocarbon ages and the sharp increase in the sedimentation accumulation rate clearly indicate that, during this period, sedimentation was strongly augmented by reworked material and that the bio-proxies may have been contaminated. Our interpretations must therefore be viewed with caution, and assumptions about environmental dynamics may not be possible for this time period (see further discussion below, 5.2.4). However, it should be noted that the low charcoal signal is in any case evidence of a decrease in fires and that the increase in algal spores and dung fungal spores cannot be inherited from older sediments that were poorer in such indicators.

Then, during the Hellenistic period (2400-2300 to ca. $2000 \mathrm{cal}$ $\mathrm{BP}, 450 / 350$ to ca. $50 \mathrm{BCE}$ ), the sediment accumulation rate and flood frequency gradually decrease (Figs. 3 and 7, sedimentary unit L4). At the same time, a sharp increase in Olea pollen, with percentages reaching $30 \%$ of the TLP, indicate that olive groves around the lake are very likely. A concomitant charcoal increase indicates the use of fire in this new phase of land clearing for olive cultivation at the expense of the deciduous oak stands that were connected to a biodiversity minimum. The influx of dung fungal spores reached a maximum, probably related to significant grazing pressure in the watershed of the lake.

After 2000 cal BP, this new landscape was characterised by a patchwork of Mediterranean woodland (e.g. evergreen oak), maquis (e.g. Erica sp.) and phrygana (e.g. Sarcopoterium-type) with reduced biodiversity (Figs. 6 and 7). The presence of olive groves also remained stable for nearly 1000 years (until 1300 cal BP), i.e. all the Roman and early Byzantine periods (from 50 BCE to 650 CE). In Crete, ancient historians (e.g. Harris, 1999) place emphasis on wine production and export. Few refer to amphorae as a proxy for olive oil export even if archaeological remains of olive-oil production were found at several Roman-period sites (Gallimore, 2017). But, there is little doubt from Kournas that olive production was highly significant and may well have been exported. At this time, annual crop indicators remain low, but grazing indicators are still present, possibly connected to increased pastoral activities and/or animal manure being brought onto the olive groves. Only a few thick flood deposits and MWD interrupt the background sedimentation which change slightly to more detrital and allochthonous sources (Figs. 3 and 7, sedimentary units L5 and L6). Almost no fires are recorded, which attests to a change in agropastoral practices.

For the first time, local archaeological data are available. An important settlement developed about $6 \mathrm{~km}$ southeast from Lake Kournas during the Hellenistic period: the city of Lappa. Numerous amphorae stamps from the wider Mediterranean attest to Lappa's position in the Hellenistic exchange network. Lappa also flourished during the Roman period as an important node in the Roman economy, linked to both its productive hinterland and the wider Roman world (Bowsky and Gavrilaki, 2010, p. 199). Two Cretan cities, one of which was Lappa, continued to mint coins into the third-century C.E. Therefore, the city must have remained a significant economic actor up until at least this moment in time (Gallimore, 2011, p. 79).

Moving into the First Byzantine Period, there is no clear archaeological evidence for settlement close to the lake. After 650 $\mathrm{CE}$, a gradual and long-lasting decrease of Olea and a concomitant decrease of evergreen oak began accompanied by an increase in 
biodiversity (Fig. 7). This coincides with the Arab conquest of Byzantine territories in regions such as the Levant and North Africa, and the first Arab siege of Constantinople (674-678 CE), which disrupted maritime trade in products such as olive oil.

\subsubsection{From the Saracen conquest to modern times (1150 cal BP to the present)}

The onset of the last phase in the environmental history of Lake Kournas fits with a moderate-amplitude and short-lived period of fire increase, which is also the last one of the record, attesting to the disappearance of fire use by people in the area (Fig. 7). This step lasted from 1150 to 750 cal BP (800-1250 CE) and is contemporary with the Arab/Saracen occupation of Crete (824-961 CE) and the 2nd Byzantine Empire (961-1204 CE). Mediterranean woodland decreased continuously from 1000 to 600 cal BP (950-1350 CE, Fig. 6). A coeval and long-term decrease of evergreen oak was also observed in the White Mountains, some kilometres south of Lake Kournas (Jouffroy-Bapicot et al., 2016). While maquis prevailed in the White Mountains, the openness of the landscape near the coast benefitted the herbaceous cover, leading to a biodiversity index increase. In terms of sedimentation, unit L6 (Figs. 3 and 7) is characterised by few event deposits but more allochthonous background sedimentation that reflects long-lasting soil erosion in the watershed.

During the Venetian period, which lasted from 1204 to 1669 CE, historical data suggest that the Venetian administration favoured grapes and other crops in Crete at the expense of olive cultivation (Stallsmith, 2007). At Lake Kournas, the continued decline of Olea pollen is in good agreement with historical data. Woodland continued to decline as well, while human activity indicators like Triticum-type pollen and dung fungal spore percentages did not increase in quantity (Figs. 6 and 7). Regarding vine, it is very hard to identify viticulture phases in the Kournas pollen record because wild vines have been an important part of the Lake Kournas littoral vegetation, and Vitis pollen is abundant throughout the sequence (Figs. 1 and 6 and SM7a), especially as wild varieties may produce more pollen than cultivated ones. To complete this discussion about Venetian land use in this area, a description of the lake by Christoforo Buondelmonti in the first part of the 15th century (Buondelmonte, 1422/1981) was rather negative: "a deep and dark little lake that frightened men”. Thus, near Lake Kournas, the major depletion of woody cover may then be related to wood exploitation for timber and/or shipbuilding (Rackham and Moody, 1996; Nixon et al., 2009), as recently hypothesised for the coeval decrease of evergreen oak in the White Mountains (Jouffroy-Bapicot et al., 2016). It is coeval with an increase of herbaceous taxa, such as Poaceae and Cichorioideae; the latter is a fenestrate pollen-type (of the Asteraceae family and also named Cichorieae) and is a good indicator of open habitats, related or not to pastoralism (Florenzano et al., 2015).

After a period of instability and war, the Ottoman conquest of Crete was completed in 1669 CE. At Kournas, from the 17th century CE onward, olive cultivation increases again locally. Historical sources show that in Crete, olive production, mainly destined for soap factories, became an economic activity favoured by the Turkish administration (Stallsmith, 2007). From the late 19th century onwards, the Olea percentages in the upper part of the sequence reach values comparable to those from the Hellenistic and Roman periods, olive groves being dominant in the present-day local landscape (Fig. 1).

\subsection{From woodland to agro-ecosystems}

\subsubsection{The Holocene Mediterranean woodlands}

The Lake Kournas sequence records almost ten millennia of local and regional vegetation dynamics and thus offers an opportunity to address the issue of natural vegetation in this part of Crete. First, throughout the Holocene woodland represent a meaningful part of the land cover around the lake, while nowadays it is scarce as in typical Aegean landscapes (Figs. 6 and 7). In these woodlands, deciduous and evergreen oaks, with a general dominance of the latter, were key species from the onset of the record.

During the Early Holocene, between ca. 9600 and 8500 cal BP, deciduous oak-dominated. Given that the climate of this period was very continental, it could well be that deciduous trees were advantaged by frequent winter frost, if compared to very frostsensitive evergreen oaks. Nowadays in Crete, deciduous oaks, namely Q. pubescens and Q. ithaburensis subsp. Macrolepis are scattered and located in inhabited places (Rackham and Moody, 1996; Fielding and Turland, 2008). Although we cannot determine the species, our data show that deciduous oak was an important part of the woodland during the early Holocene, and even after its sharp decrease at around $8500 \mathrm{cal} \mathrm{BP}$, it remained important until the last century.

For ca. 8500 years, evergreen oak pollen dominated, although, unfortunately, pollen morphology does not allow the identification of the species. Nowadays, in Crete, two evergreen oaks cohabit: holm oak ( $Q$. ilex) and kermes oak ( $Q$. coccifera). Kermes oak is common in various habitats (Goedecke et al., 2018) and has high resilience capacity. It is particularly well adapted to drought, fire and grazing (Rackham and Moody, 1996) and can flower even in a degraded state (Fielding and Turland, 2008). Conversely, holm oak, which is more sensitive to human pressure as a taller latesuccessional species, is restricted to specific areas (Goedecke et al., 2018). Recent palaeoecological studies demonstrated that natural- or human-driven fires can disadvantage holm oak (Colombaroli et al., 2009). Declining fire activities together with Q. ilex expansions have been observed at many sites in the Mediterranean and can be explained by climatic shifts controlling both fire and vegetation change and/or complex fire-species interactions (Tinner et al., 2009; Beffa et al., 2016). At Kournas, during the first part of the Middle Holocene (between ca. 8500 and 6000 cal BP), evergreen oak pollen percentages rose during a period of moderate charcoal sedimentary accumulation and decreased sharply as biomass burning increased (Fig. 7). Thus, near the lake, holm oak may have had a more significant place in the Early- and Middle Holocene woodland when human impact was low, than in the present-day vegetation.

Pollen of more northern European trees, namely Alnus, Betula, Corylus and Fagus have been regularly registered throughout the sequence, except in the most recent samples (Fig. SM7a). They are currently absent in the Cretan flora, or, as for Corylus avellana, are doubtfully native (Fielding and Turland, 2008). Such observations indicate that these trees might have been part of the original Cretan postglacial forest. Alternatively, the presence of such pollen grains could be the result of long-distance transport, as proposed by Bottema and Sarpaki (2003). The former may support the hypothesis that modern land use would not leave much space for trees such as alder (Alnus), birch (Betula), hazelnut (Corylus), and beech (Fagus). Ulmus/Zelkova pollen almost disappear after 700 cal BP, probably corresponding to a decline of elm trees presence, even if elm (Ulmus minor) is relatively common around Lake Kournas today. It is not possible to distinguish Ulmus pollen from the endemic Zelkova abelica pollen; this tree that grows above $850 \mathrm{~m}$ today (Fielding and Turland, 2008) was probably less important in the local pollen rain than elm. However, the hypothesis that it was present on the hills near the lake during the Holocene cannot be ruled out. First clues about maquis development occurred around 8000 cal BP with the occurrence of Erica and Phillyrea pollen grains. The increase in the phrygana occurred after ca. 3500 and is well 
illustrated by the Sarcopoterium pollen curve. This dynamic led to the present-day mosaic of vegetation accompanying olive groves in the surroundings of the lake.

\subsubsection{Land use, land cover and biodiversity}

In the highly anthropized current landscape around Lake Kournas, the olive tree occupies an important place (Fig. 1). Olea pollen is also of prime importance in the palynological record, indicating that olive, probably the most iconic tree of the Mediterranean (e.g. Izdebski et al., 2020; Kouli et al., 2018; Langgut et al., 2019) has had a major role in the local socio-ecosystem. The history of olive tree cultivation at Kournas can be divided into three main phases: the Final Neolithic-Minoan period, the Hellenistic-RomanByzantine (HRB) period and Modern times. A similar trend in olive pollen is observed across the whole of southern Greece (Weiberg et al., 2019). The first phase onset at Kournas, 6000 yrs ago, confirms the age proposed by Langgut et al. (2019) recent synthesis based on published data from Greece (Avramidis et al., 2013) and Crete (see section 5.1.3). At that time, during the Final Neolithic, archaeologists argue for an expansion in settlement (Tomkins, 2008) and a significant increase in activity (Nowicki, 2014; Weiberg et al., 2016). There is little doubt that olive exploitation continued during the Minoan period. That is in good accordance with archaeological evidence of oil storage , presence of archaeobotanical remains of olive wood, fruits and pollen (Badal and Ntinou, 2013; Cañellas-Boltà et al., 2018; Ghilardi et al., 2018; Livarda et al., 2021; Moody, 2012). The socioeconomic importance of olive trees in Minoan Crete is documented by archaeological finds (e.g. Hamilakis, 1996; Riley, 2002), and is attested in Linear B tablets (Killen, 2016). The second phase during the HRB period, with the persistence of olive cultivation together with stabilisation of other environmental markers (erosion, fire, biodiversity), is striking. Contrary to what Bonnier and Finné (2020) suggested in the North-Eastern Peloponnese at the regional level, we do not see here any adaptation and/or change in land-use during the drier conditions of the Late Hellenistic-Roman period. Young olives, in particular, require high levels of watering (Foxhall, 2007, p. 110); thus, the location of extensive olive groves adjacent to a lake makes perfect sense. Finally, the last phase of olive cultivation, beginning during the Turkish period, lays the foundation of the current land use and the current landscape.

Another land-use well documented by the lake Kournas record is pastoralism. Coprophilous fungi are recorded throughout the sequence from at least $8500 \mathrm{cal} \mathrm{BP}$, and more regularly since 3500 cal BP. Today, flocks of sheep and goats extensively graze or browse mainly on the western slopes. The amounts of coprophilous fungi are comparable to the present-day quantities accumulated in the core-top sediments (an average of 100 spores of Sporormiella/ $\mathrm{cm}^{2} /$ year). Combined with the assemblage of grazing-related pollen taxa such as Urtica or Rumex acetosa-type, we can probably consider they are robust indices of a persistent local presence of domestic and/or feral animals. The huge increase of these proxies' values during the Classical, Hellenistic and Roman periods correlate with the historical sources that highlight the importance of livestock breeding in Crete (Fig. 7). Milk and derived milk products represented a vital part of the food economy, and breeding became a specialized activity (Chaniotis, 1999). Nevertheless, the very high amplitude of the fungal spore peaks at that time may also be related to changes in the sediment accumulation rate and the related quantity of soil-eroded inputs. Fungal spore representation can be overestimated because of geomorphic processes like soil erosion (Etienne et al., 2013), maybe themselves favoured by grazing. Finally, we can also consider manuring across the olive groves or the purposeful movement of animals for short periods across the groves to fertilise. Indeed, high amounts of coprophilous fungal spores in the palynofacies may also originate from manured soils (Graf and Chmura, 2006).

How did these land uses throughout Kournas' landscape history interplay with plant biodiversity? As observed in other studies within the southern Mediterranean (e.g. Colombaroli and Tinner, 2013), the main changes in pollen biodiversity are correlated with land use during the Mid- and Late-Holocene. Apparently, some land uses and/or land management schemes were more favourable to biodiversity development or conservation, while others were destructive. From 6000 to 3000 cal BP, i.e. the Final Neolithic to the end of the Minoan period, biodiversity was high (Fig. 7). Our data indicate a sustainable agro-pastoral system with a balance of pastoralism, annual crops and olive cultivation that led to manageable disturbances, i.e. with a level of intensity below the resilience ability of these anthropized ecosystems. For example, throughout the Minoan period, animal husbandry and crop cultivation led to more fires, a biodiversity increase and fewer flood deposits. Afforestation periods were matched by an increase of flood frequency and biodiversity decline. It is thus possible to hypothesize that a diversity of land use and the related micro-scale diversity of ecosystems preserved soils from storm erosion and promoted landscape-scale biodiversity (Connor et al., 2019). These land uses with moderate disturbance levels, maybe under different climate conditions, favoured vegetation biodiversity. Conversely, the 1300 years of long-lasting and well-established HRB land uses, involving intensive olive cultivation and sizable livestock in the watershed, were coeval with a sharp decrease in the pollen biodiversity indicators (Fig. 7). These HRB pollen assemblages and biodiversity values are strongly comparable to the top core samples. Even considering the limits of the paleoenvironmental proxies used in this study, the HRB olive cultivation looks a lot like today's intensive land use. The commonalities might be rooted in the largescale production of goods with specialization for long-distance trading. Thus moderate disturbance based on a controlled fire regime combined with non-intensive agro-pastoral activities may favour biodiversity while too intense or too few disturbances limit it. At Kournas, the non-linear biodiversity trend highlights the ecosystem's resilience, especially during the post-HRB decline in cultivation (Fig. 7). The decreasing trend in pollen-inferred biodiversity in most recent samples is in accordance with studies showing the role of agro-pastoral systems in land degradation since the mid-1980s, with a guilty role of intensive breeding on Crete (Ispikoudis et al., 1993; Kosmas et al., 2016) and of olive monoculture at the Mediterranean basin scale (Moreira et al., 2019).

\subsubsection{A human-driven fire regime}

Fire is a widespread and key disturbance in Holocene Mediterranean ecosystems, controlled by both climate conditions and humans (e.g. Vannière et al., 2008, 2011). Climate is proposed as the main driver of Early Holocene fire regimes even if the human role for this period is probably underestimated (Lawson et al., 2013) because of the lack of direct evidence. In contrast, farming practices certainly deeply modified if not controlled the fire regime at least since the Neolithic throughout the basin (Connor et al., 2019; Vannière et al., 2016). Site-scale studies on several Mediterranean islands: Corsica (Lestienne et al., 2020), Sardinia (Beffa et al., 2016), Sicily (Tinner et al., 2009, 2016), Malta (Marriner et al., 2019) clearly show how fire occurrences were closely associated with land-use rhythms after about 7000 cal BP. They altered the "natural" frequency of events but likely also the intensity, severity, location and size-area of the fire events according to human purposes and landuse modes.

The synchronicity of charcoal peak-accumulation in lake sediments at Kournas with pollen indicators of human activities throughout the record argues for a causal link between humans and 
fire (Fig. 7). Moreover, several phases with high biomass burning may have occurred synchronously with wet and cold climate periods in Crete as documented by the literature (see section 5.3.1, Cheng et al., 2015; Dean et al., 2015; Finné et al., 2014, 2019; Rohling et al., 2002, 2015, 2019), which might have been expected to reduce fires in Kournas area. Fire has certainly been used as a pastoral management tool and was still used until recently in traditional mountain land management on Crete, where shepherds used burning to make the herbaceous flora more abundant and palatable. Fire also seems to be involved in land clearing before the initial establishment of olive groves during Classical Greek times (Fig. 7). It is more difficult to characterise the first fire phase during the Early Holocene, i.e. before 8500 cal BP and to decipher an early human impact of some possible Mesolithic or PPN Neolithic groups.

\subsubsection{Land cover changes and sediment dynamic responses}

Since Vita-Finzi (1969) assessment of historical Mediterranean soil erosion, the debate has almost never stopped about the causes and the degree of "degradation" of Mediterranean landscapes, mainly concerning soil loss (e.g. Lespez, 2003; Thornes and Wainwright, 2004; Butzer, 2005; Hooke, 2006; Fuchs, 2007; Walsh et al., 2019). Dusar et al. (2011) proposed a regional synthesis for the Eastern Mediterranean about the timing and drivers of Holocene sediment dynamics, and showed that since the midHolocene, with lags between sites according to local history, human impact can explain sediment flux to a large extent. The comparison of flood frequencies from Kournas with sedimentation history records during the Holocene from Crete in particular (Macklin et al., 2010; Benito et al., 2015) or from the Eastern Mediterranean region (Dusar et al., 2011; Benito et al., 2015), does not show any clear regional pattern that could argue for climate as a dominant driver of Holocene flood history at Kournas.

Sedimentation in the lake basin started from $9600 \mathrm{BP}$, but real lacustrine sediments accumulated only from 8500 cal BP. The continuing marine transgression might have favoured the lake set up at this time. The first fluvial deposit was recorded from $8400 \mathrm{cal}$ $\mathrm{BP}$ onward. From this first event, all flooding periods in Lake Kournas correlate remarkably well with other environmental changes connected, at least in part, with human impact. The first phase of flooding follows the evergreen oak expansion and the increase in grazing indicators (Fig. 7). Around 6000 cal BP, it likely derived from forest disruption (mainly evergreen oak) and just preceded the start of olive cultivation. Around $4000 \mathrm{cal} \mathrm{BP}$, a rise in flood frequency matches again with a new increase in Olea. From 2700 to 2000 cal BP (800-200 BCE), the major flood events overlap in time with the onset of the strong and long-lasting phase of HRB olive cultivation together with animal husbandry.

The thickest flood deposits often preceded an olive pollen maximum and were thinner afterwards. Only the initial phase, probably related to land clearing, was coeval with intense soil erosion (Fig. 7). Subsequently, olive cultivation likely included some soil management to mitigate erosion. Karamesouti et al. (2015) described such a process for the modern period in the Messara Plain in southern Crete (1950-2010). However, the continuous occurrence of flood deposits throughout the period of olive cultivation means that long-term changes in land cover must have led to fundamental hydrological changes in the watershed. For example, changes in the landscape connectivity, of soil thickness and properties, might have increased the transport capacity of water and the sediment mobilized through erosion after being initiated by deforestation and grazing (Hooke, 2006). Thus, the flooding record at Lake Kournas likely represents a signal of local land use, often resulting from vegetation disturbance for agro-pastoral purposes, such as observed at lake Nar in Turkey (Roberts et al., 2018).

The individual causes of the MWDs that represent internal lake sediment movements remain unclear, with the exception of the one that is coeval with the crypto-tephra signal linked to the Minoan eruption of Santorini. For the others, no precise chronological correlations can be established with the seismic activity reported in the literature (e.g. Mourtzas et al., 2016; Polonia et al., 2016; Jusseret and Sintubin, 2017). The first MWD followed the onset of woody vegetation 4000 years ago and some reorganization of land use around the lake circa the beginning of the Middle Minoan period. However, all MWD occurred during periods of increased Olea pollen. The sedimentary dynamics also seem stronger after ca. 4000 cal BP elsewhere in Crete (Benito et al., 2015), in mainland Greece (Lespez, 2003; Fuchs, 2007; Engel et al., 2009) and in the wider Eastern Mediterranean (Dusar et al., 2011), as at Kournas. This new stage in regional sediment dynamics might be associated with the widespread increase of human population and a threshold passed in land cover. This transitional period has also been identified in the flood frequency record from the north-western Mediterranean due to the combined effect of land use and climate (Vannière et al., 2013; Rapuc et al., 2019).

Between 2700 and 2300 cal BP, a possible cause of the significant increase of the sedimentation accumulation rate was the reworking of sediment within the lake itself, in particular from the shallow ( 5-6 $\mathrm{m}$ deep) shelf zone toward the deep basin. The reversal in ${ }^{14} \mathrm{C}$ ages during sedimentary unit L3 (Fig. 4) clearly reflects the re-working of organic macrofossils, along with more diffuse soil carbon, and these may have been derived from sediments previously deposited in the shallow marginal zone of the lake. The 500 years of rapid accumulation in Kou11-12, overlaps with a longer hiatus seen in unpublished cores taken in the shelf zone by another project in 2000-2001 (Jason Curtis, pers comm.; Besonen et al., 2011). If so, then the most likely cause would have been a fall in lake level of a few metres, sufficient to alter the sediment limit in the shelf zone. With the marginal zone of sediment storage no longer in operation, eroded soil could have moved directly from the catchment into the lake's deep basin.

In the most recent pan-Mediterranean synthesis of erosion dynamics by Walsh et al. (2019), the Greek and Roman periods appear as critical moments, and more locally, a "Roman paroxysm" for sediment flux has also been recorded in Crete (Macklin et al., 2010; Ghilardi et al., 2018). The respective roles of Greco-Roman land management intensification and climate conditions needs further investigation (Benito et al., 2015; Walsh et al., 2019). In the Kournas watershed, the intensification of agro-pastoral activities during Greco-Roman Antiquity is obvious. It corresponds to a significant reduction in both the frequency and magnitude of floods but also to a coarser and a new carbonate detrital component in the lacustrine sedimentation (see ratios $\mathrm{Sr}: \mathrm{Ca}, \mathrm{Ca}: \mathrm{Al}$ and $\mathrm{Zr}: \mathrm{Al}$, sedimentary units L4, L5 and L6, Fig. 3), which lasts and intensifies during the last two millennia. Thus, we hypothesize that in the watershed of Kournas, soils may have been strongly modified during the first millennium BCE. This soil transformation may have led to new hydrological patterns, which in turn led to long-lasting erosion, especially via surface runoff (Hortonian flows; see Hooke, 2006), that modifed consecutively, deeply and lastingly the regular lake sedimentation.

\subsubsection{Climate changes and environmental responses}

Independent proxies from speleothems (Finné et al., 2014; Cheng et al., 2015), sea surface temperature (e.g. Rohling et al., 2015), terrestrial biomarkers from sea sediments (Gogou et al., 2007; Kouli et al., 2012) and lacustrine geochemistry (e.g. Dean et al., 2015) document Holocene climate variations in the eastern Mediterranean. The results are sometimes contradictory, and the recent synthesis by Finné et al. (2019) highlights the spatial complexity of past climate changes in the Eastern Mediterranean. Thus, any inference of a precise pattern of temperature and 
precipitation changes in the Eastern Mediterranean and, a fortiori, at the scale of Western Crete is still difficult.

From ca. 8700 to 7800 cal BP, the Kournas record is characterised by a rapid succession of events leading to one of the main shifts in the area's environmental history (transition from Kournas phase 1 to 2, Fig. 7). Sediments indicate an evolution from a shallow water body to a deeper lake basin (Units L0 to L1, Fig. 3) and the occurrence of flood deposits. This transition is recorded by the enrichment of the sedimentary content in algal remains and in particular, of Tetraedron minimum (AZ 1 b, Fig. SM9), and an important change in diatom assemblage (DZ 2, Fig. SM11). Tetraedron minimum is a green coccal algae characterised by its ability to use inorganic carbon (van Hunnik et al., 2000) and likely benefited from lake ontogeny. The dominance of planktonic diatoms and taxa preferring low salinities indicates that Lake Kournas has been a relatively deep, freshwater body for most of the record. The exception to this occurred between $\sim 8400$ and $\sim 7800$ cal BP, when there was a very marked diatom-inferred increase in lake salinity. The dominance of the Actinocyclus normanii at this time could, in theory, have been caused by an incursion of marine water into the lake, which today lies close to the coast. This period coincides with the last significant rise in global eustatic sea levels (e.g. Perissoratis and Conispoliatis, 2003; Vacchi et al., 2016). On the other hand, at the same time, sedimentation became more detrital and enriched in numerous elements from the watershed (Fig. SM4). The likely interpretation is that the shift in sediment dynamics on the watershed, including the newly flood deposits, and combined with sea-level rise blocked surface water outflow from the lake. This may have been associated with a drier period around the time of the 8.2 ka climate event (Daley et al., 2011), which lowered the water level of Lake Kournas to become a closed (i.e. non-outlet) system, preventing solutes from been removed via the stream outflow. The 8.2 ka event, which is also described as a pluri-secular climate change period, is recorded elsewhere in the eastern Mediterranean as a period of climatic aridity (e.g. Dean et al., 2015) and cooling (Gogou et al., 2007 ) is registered in some regional pollen records by a shortlived decline in woodland (Pross et al., 2009; Kouli et al., 2012). This is not the case at Kournas, although a land cover change did take place from deciduous to evergreen oak-dominated forest at around 8400 cal BP, at the very onset of the salinity increase.

During the Mid and Late Holocene, there is no clear and obvious relationship between reconstructed or modelled climate shifts (e.g. Mayewski et al., 2004; Kouli et al., 2012; Rohling et al., 2019) and vegetation or the environment at and around Lake Kournas (Fig. 7). In contrast, the key steps in environmental change at Kournas can be connected to land use and so with human drivers. For instance, 6000 years ago, a new increase in flood frequency and then fire signal were coeval with the Olea expansion and seem to have occurred before the onset of a "cold and wet winter period" at 6000-5000 cal BP (Mayewski et al., 2004; Kouli et al., 2012; Rohling et al., 2019). On the other hand, the change at Kournas was broadly coincident with the end of the regional phase of wetter Neolithic climate in the eastern Mediterranean (Finné et al., 2019), associated with the mid-Holocene climatic transition (Roberts et al., 2011), and this may have favoured taxa adapted to seasonal drought such as olive. More specifically, there is no evidence in the Kournas record of the $4.2 \mathrm{ka}$ BP climate event, although there were changes at Kournas (e.g. flood events) during and after $3.2 \mathrm{ka}$ BP, a period of regional climatic aridity that has been linked to the end of the Late Bronze Age world system in the eastern Mediterranean (Kaniewski et al., 2013). The major phase of increased sedimentation and flood frequency 2700 and 2300 cal BP, was partly linked to the establishment of HRB olive cultivation, but also possibly in the context of lake-level lowering and a drier climate (Benito et al., 2015; Finné et al., 2019). So, the onset of HRB land use and a change in precipitation regime may have both favoured soil erosion. Finally, during the Late Holocene, the Medieval Climate Anomaly and Little Ice Age coincided with some local environmental changes, including a slight diatom-inferred increase in lake water salinity, but the politico-economical context also provides a valid explanation for most of these changes and their timing (see above part 5.1.5).

\subsubsection{The Santorini Minoan tephra and regional seismic activity}

In the Aegean, the most discussed past volcanic event is the "Santorini/Thera" eruption and its environmental and social impact (e.g. Walsh, 2014: 20-23). A volcanic ash deposit, the so-called Minoan tephra, has been observed in many sedimentary contexts in Greece (e.g. Friedrich et al., 2006a, 2006b), in Crete (Driessen, 2019), and as far as western Turkey (Sulpizio et al., 2013) wind having favoured ash transport to the east. At Kournas, the question of this tephra and the subsequent effect on local vegetation was one of the goals of the Bottema and Sarpaki paper (2003). The authors identified a layer with pumice stones and volcanic glass in the Delphinos sequence that they related to the Santorini eruption, but did not regard it as in situ deposition. In the Lake Kournas sequence, geochemical analyses have shown a crypto-tephra deposit within the lake sediment, dated between 3370 and 3560 cal BP. It caps a MWD (Fig. SM6) and has been recognized as the Thera eruption signature. The reworked sediment might have been the consequence of earthquakes that preceded or took place during the eruption and that are also responsible for damage to Minoan palaces (Jusseret et al., 2013; Driessen, 2019). However, there was no marine intrusion into the lake due to a tsunami, nor any flash-flood event following the tephra deposit. This seems to confirm that in West Crete, the eruption impact may have been lower than in the East (Driessen, 2019). Similarly, no significant shift can be identified in the vegetation around Kournas at or just after the tephra layer. Nevertheless, a change in agro-pastoral practices occurred at and after ca. 3500 cal BP (Fig. 7), when Olea declined and cereal cultivation expanded (Fig. 6, PZ 3c). As suggested by tree-ring analysis (Pearson et al., 2009), a more humid climate could have damaged olive trees and/or decreased their productivity, which may have prompted an increase in cereal farming. Riley (2012) already proposed volcanic damage to Late Minoan olive groves following Eastern and Central Crete archaeological evidence.

\section{Conclusion}

Kournas' record provides novel insights into the timing and nature of vegetation, biodiversity, fire, land use and environmental shifts. Ecosystem development near Lake Kournas was not a linear process but involved linkages and feedbacks between vegetation, biodiversity, fire, human impact, erosion, and climate change. Among these, human impact was probably the most important driver of ecosystem change during the past $\sim 8000$ years. Lake Kournas as a natural archive has a high value in providing new insights about human history in western Crete, a region where archaeological remains are relatively scarce. Pollen and fungal remains suggest possible human activities around the lake as early as 9500 cal BP, perhaps in a transitional phase between the Mesolithic and the Neolithic. With more confidence, the establishment of an agrosystem after 8500 years ago means that the trajectory of Kournas' lake and catchment ecosystems during the Mid to Late Holocene follow the rhythm of land-use change.

The main exception to this was the period $\sim 8500$ - 8000 cal BP, when the local sediment regime, probably driven by sea-level rise and climate-related lake level changes, led initially to the establishment of a deep lake, then a period of lake outlet closure and salinity increase, climatic conditions may have promoted the 
expansion of the evergreen oak woodland.

Among the traditional Mediterranean land uses, olive cultivation locally played a major role in the socio-ecosystem interactions, providing economic benefits but also destabilising soils. During the last six millennia, three main phases of olive cultivation occurred, interrupted by periods when olive groves were abandoned or used less intensively; some of them lasted for millennia (e.g. from the Final Neolithic to the Minoan). The changing land use under the successive political and economic influences permitted the resilient vegetation to shift back to growing higher biodiversity again. Forest vegetation was always able to recover until the onset of the Venetian period (13th century), when woodlands were dramatically reduced. Only during the past century has forest vegetation slightly recovered, while the flood regime had already been altered during previous centuries. During the past 100 years, biodiversity markedly declined, probably in response to the industrialization of agriculture. Moreira et al. (2019) argued that in a global context of the growing demand for olives and olive oil, it is urgent to move to a more sustainable form of production that conserves biodiversity and preserves the soil. Kournas' environmental history provides a target for such a sustainable socio-ecosystem.

\section{Author contributions}

Concept, methodology, data curation, writing-original draft: IJB* and BV*, Analysis: IJB, BV, TP, MD, RS, GZ, FS, PS, Data validation and interpretation, and manuscript editing: IJB, BV, TP, MD, GZ, PS, NR, WT, KW, Project conceptualization, administration and funding acquisition: BV. All authors agreed with the published version of the manuscript. * IJB and BV contributed equally to this work.

\section{Funding}

This research was funded by Région Bourgogne-Franche-Comté through Chrono-environnement laboratory, the MSHE (Maison des Sciences de l'Homme et de l'Environnement) and the project ENVILEG (Héritage environmental des grandes transitions socioécologiques en Europe) led by Boris Vannière. This study was also supported by the CNRS PaléoMEx-MISTRALS (Mediterranean Integrated STudies at Regional And Local Scales) program. Coring and geological fieldwork has been authorized (Work permit $\mathrm{N}^{\circ} 354$ ) by the Institute of Geology and Mineral Exploration (I.G.M.E).

\section{Author statement}

Jouffroy-Bapicot Isabelle*: Concept, methodology, data curation, analysis, writing-original draft, data validation and interpretation, and manuscript editing. Pedrotta Tiziana: Analysis and manuscript editing. Debret Maxime: Analysis, data validation and interpretation, and manuscript editing. Field Sophie: Analysis, and manuscript editing. Sulpizio Roberto: Analysis, and manuscript editing. Zanchetta Gianni: Analysis, data validation and interpretation, and manuscript editing. Sabatier Pierre: Analysis, data validation and interpretation, and manuscript editing. Roberts Neil: Analysis, data validation and interpretation, and manuscript editing. Tinner Willy: Data validation and interpretation, and manuscript editing. Walsh Kevin: Data validation and interpretation, and manuscript editing. Vannière Boris*: Concept, methodology, data curation, analysis, writing-original draft, data validation and interpretation, and manuscript editing. * contributed equally to this work.

\section{Declaration of competing interest}

The authors declare that they have no known competing financial interests or personal relationships that could have appeared to influence the work reported in this paper.

\section{Acknowledgements}

Many thanks to Agnès Stock, Julien Didier, Maxime Mermet, Antoine Hache, Guillaume Meunier, Matthieu Le Bailly and Mathieu Ghilardi for their help during fieldwork and lab analyses. Thanks to Fabien Arnaud, Jerôme Poulenard and Anne-Lise Develle for their discussion on sedimentological and geochemical data, and to Jessie Woodbridge and Katie Head for their help with diatom analysis. Thanks also to Marion Lestienne and Simon Connor for kindly providing $R$ code and support. The authors warmly thank the $P_{E A^{2} t}$ platform (Chrono-environment, University of Bourgogne FrancheComté, UMR CNRS 6249, France), which manages and maintains the analytical equipment used in this study. Kevin Walsh would like to acknowledge the support of IMéRA, Aix-Marseille University, France, Cofund EURIAS, Labex RFIEA + and ANR-Investissements d'avenir. In addition, our gratitude goes to Panos Zervoudakis, who provided background information on the archaeology around Kournas and Nena Galanidou who facilitated a visit to the area. The authors are pleased to acknowledge the two anonymous reviewers, whose comments and suggestions have greatly strengthened the paper.

\section{Appendix A. Supplementary data}

Supplementary data to this article can be found online at https://doi.org/10.1016/j.quascirev.2021.107072.

\section{References}

Agou, V.D., Varouchakis, E.A., Hristopulos, D.T., 2019. Geostatistical analysis of precipitation in the island of Crete (Greece) based on a sparse monitoring network. Environ. Monit. Assess. 191, 353. https://doi.org/10.1007/s10661-0197462-8.

Appleby, P.G., 2001. Chronostratigraphic techniques in recent sediments. In: Last, W.M., Smol, J.P. (Eds.), Tracking Environmental Change Using Lake Sediments. Basin Analysis, Coring, and Chronological Techniques, Developments in Paleoenvironmental Research. Kluwer Academic Publishers, Dordrecht, The Netherlands, pp. 171-203.

Appleby, P.G., Richardson, N., Nolan, P.J., 1991. 241Am dating of lake sediments. Hydrobiologia 214, 35-42. https://doi.org/10.1007/BF00050929.

Atherden, M.A., Hall, J.A., 1999. Human impact on vegetation in the white mountains of Crete since AD 500. Holocene 9, 183-193. https://doi.org/10.1191/ 095968399673523574.

Avramidis, P., Geraga, M., Lazarova, M., Kontopoulos, N., 2013. Holocene record of environmental changes and palaeoclimatic implications in Alykes lagoon, Zakynthos island, western Greece, Mediterranean sea. Quat. Int. 293, 184-195. https://doi.org/10.1016/j.quaint.2012.04.026.

Azuara, J., Sabatier, P., Lebreton, V., Jalali, B., Sicre, M.-A., Dezileau, L., Bassetti, M.-A., Frigola, J., Combourieu-Nebout, N., 2020. Mid- to Late-Holocene Mediterranean climate variability: contribution of multi-proxy and multi-sequence comparison using wavelet spectral analysis in the northwestern Mediterranean basin. Earth Sci. Rev. 208, 103232. https://doi.org/10.1016/j.earscirev.2020.103232.

Badal, E. Ntinou, M., 2013. Wood charcoal analysis. In: Efstratiou, N. (Ed.), The Neolithic Settlement of Knossos in Crete. New Evidence for the Early Occupation of Crete and the Aegean Islands, Prehistory Monographs 42. INSTAP Academic Press, Philadelphia, Penssylvania, pp. 95-118.

Bajard, M., Sabatier, P., David, F., Develle, A.-L., Reyss, J.-L., Fanget, B., Malet, E., Arnaud, D., Augustin, L., Crouzet, C., Poulenard, J., Arnaud, F., 2016. Erosion record in lake La thuile sediments (Prealps, France): evidence of montane landscape dynamics throughout the Holocene. Holocene 26, 350-364. https:// doi.org/10.1177/0959683615609750.

Bajard, M., Poulenard, J., Sabatier, P., Bertrand, Y., Crouzet, C., Ficetola, G.F., Blanchet, C., Messager, E., Giguet-Covex, C., Gielly, L., Rioux, D., Chen, W., Malet, E., Develle, A.-L., Arnaud, F., 2020. Pastoralism increased vulnerability of a subalpine catchment to flood hazard through changing soil properties. Palaeogeogr. Palaeoclimatol. Palaeoecol. 538, 109462. https://doi.org/10.1016/ j.palaeo.2019.109462.

Baker, A.G., Bhagwat, S.A., Willis, K.J., 2013. Do dung fungal spores make a good proxy for past distribution of large herbivores? Quat. Sci. Rev. 62, 21-31.

Battarbee, R.W., Jones, V.J., Flower, R.J., Cameron, N.G., Bennion, H., 2001. 8: diatoms. In: Smol, J. (Ed.), Tracking Environmental Change Using Lake Sediments, Vol 3: Terrestrial, Algal and Siliceous Indicators. Kluwer Academic Publishers, Netherlands, pp. 155-202. 
Beffa, G., Pedrotta, T., Colombaroli, D., Henne, P.D., van Leeuwen, J.F.N., Süsstrunk, P., Kaltenrieder, P., Adolf, C., Vogel, H., Pasta, S., Anselmetti, F.S., Gobet, E., Tinner, W., 2016. Vegetation and fire history of coastal north-eastern Sardinia (Italy) under changing Holocene climates and land use. Veg. Hist. Archaeobotany 25, 271-289. https://doi.org/10.1007/s00334-015-0548-5.

Benito, G., Macklin, M.G., Zielhofer, C., Jones, A.F., Machado, M.J., 2015. Holocene flooding and climate change in the Mediterranean. Catena 130,13-33. https:// doi.org/10.1016/j.catena.2014.11.014.

Besnard, G., Terral, J.-F., Cornille, A., 2018. On the origins and domestication of the olive: a review and perspectives. Ann. Bot. 121, 385-403. https://doi.org/ $10.1093 / \mathrm{aob} / \mathrm{mcx} 145$

Besonen, M.R., Rosenmeier, M.F., Curtis, J.H., Weiss, H., Moody, J.A., Magill, C.R., 2011. Increasing evidence for a Pronounced, mid-1st millennium A.D. Desiccation event in the eastern Mediterranean. In: Paper Given at AUG Chapman Conference on Climates, Past Landscapes and Civilizations, vol. 832.

Beug, H.J., 2004. Leitfaden der Pollenbestimmung für Mitteleuropa und angrenzende Gebiete (Guide to the Pollen Analysis for Central Europe and the Adjacent Areas). Pfeil, München.

Birks, H.J.B., Line, J.M., 1992. The use of rarefaction analysis for estimating palynological richness from quaternary pollen-analytical data. Holocene 2, 1-10. https://doi.org/10.1177/095968369200200101.

Blaauw, M., 2010. Methods and code for 'classical' age-modelling of radiocarbon sequences. Quat. Geochronol. 5, 512-518. https://doi.org/10.1016/ j.quageo.2010.01.002

Blockley, S.P.E., Pyne-O’Donnell, S.D.F., Lowe, J.J., Matthews, I.P., Stone, A., Pollard, A.M., Turney, C.S.M., Molyneux, E.G., 2005. A new and less destructive laboratory procedure for the physical separation of distal glass tephra shards from sediments. Quat. Sci. Rev. 24, 1952-1960. https://doi.org/10.1016/ j.quascirev.2004.12.008.

Bonnier, A., Finné, M., 2020. Climate variability and landscape dynamics in the late Hellenistic and roman North-Eastern Peloponnese. Antiquity 94, 1482-1500. https://doi.org/10.15184/aqy.2020.34.

Bottema, S., Sarpaki, A., 2003. Environmental change in Crete: a 9000-year record of Holocene vegetation history and the effect of the Santorini eruption. Holocene 13, 733-749. https://doi.org/10.1191/0959683603hl659rp.

Bowsky, M., Gavrilaki, I., 2010. Klio 's clay : inscribed instrumenta domestica from Lappa (Crete) *. Creta Antica 173-253.

Bruel, R., Sabatier, P., 2020. serac: an R package for ShortlivEd RAdionuclide chronology of recent sediment cores. J. Environ. Radioact. 225, 106449. https:// doi.org/10.1016/j.jenvrad.2020.106449.

Buondelmonte, C., 1422/1981. Descriptio insule Crete; et Liber insularum, cap. XI: Creta, Reprinted with commentary by M. In: van Spitael, A. (Ed.), Ekdoseis Sullogou Politistikes Anaptuxeos Herakleiou. Herakaion Crete.

Butzer, K.W., 2005. Environmental history in the Mediterranean world: crossdisciplinary investigation of cause-and-effect for degradation and soil erosion. J. Archaeol. Sci. 32, 1773-1800. https://doi.org/10.1016/j.jas.2005.06.001.

Cañellas-Boltà, N., Riera-Mora, S., Orengo, H.A., Livarda, A., Knappett, C., 2018. Human management and landscape changes at Palaikastro (eastern Crete) from the late neolithic to the early Minoan period. Quat. Sci. Rev. 183, 59-75. https:// doi.org/10.1016/j.quascirev.2018.01.010.

Carrión, Y., Ntinou, M., Badal, E., 2010. Olea europaea L. In the north Mediterranean basin during the Pleniglacial and the early-middle Holocene. Quat. Sci. Rev. 29, 952-968. https://doi.org/10.1016/j.quascirev.2009.12.015.

Chaniotis, A., 1999. Milking the mountains. Economic activities on the cretan upland in the classical and Hellenistic period. In: From Minoan Farmers to Roman Traders. Sidelights on the Economy of Ancient Crete. Franz Steiner Verlag, Stuttgart, pp. 181-220.

Chapman, J., 2018. Climatic and human impact on the environment?: a question of scale. Quat. Int. 496, 3-13. https://doi.org/10.1016/j.quaint.2017.08.010.

Cheng, H., Sinha, A., Verheyden, S., Nader, F.H., Li, X.L., Zhang, P.Z., Yin, J.J., Yi, L., Peng, Y.B., Rao, Z.G., Ning, Y.F., Edwards, R.L., 2015. The climate variability in northern Levant over the past 20,000 years. Geophys. Res. Lett. 42, 8641-8650. https://doi.org/10.1002/2015GL065397.

Chester, P.I., Raine, J.I., 2001. Pollen and spore keys for Quaternary deposits in the northern Pindos Mountains, Greece. Grana 40, 299-387. https://doi.org/ 10.1080/00173130152987535.

Cioni, R., Marianelli, P., Santacroce, R., 1998. Thermal and compositional evolution of the shallow magma chambers of Vesuvius: evidence from pyroxene phenocrysts and melt inclusions. J. Geophys. Res. 103, 18277-18294.

Cline, E., 2010. The Oxford Handbook of the Bronze Age Aegean. Oxford University Press.

Collins, P.M., Kaplan, J.O., Davis, B.A.S., 2010. Could anthropogenic soil erosion have influenced Mediterranean vegetation distribution over the Holocene? IOP Conf. Ser. Earth Environ. Sci. 9, 012011 https://doi.org/10.1088/1755-1315/9/1/012011.

Colombaroli, D., Tinner, W., 2013. Determining the long-term changes in biodiversity and provisioning services along a transect from Central Europe to the Mediterranean. Holocene 23, 1625-1634. https://doi.org/10.1177/ 0959683613496290.

Colombaroli, D., Tinner, W., van Leeuwen, J., Noti, R., Vescovi, E., Vannière, B., Magny, M., Schmidt, R., Bugmann, H., 2009. Response of broadleaved evergreen Mediterranean forest vegetation to fire disturbance during the Holocene: insights from the peri-Adriatic region. J. Biogeogr. 36, 314-326. https://doi.org/ 10.1111/j.1365-2699.2008.01987.x.

Colombaroli, D., Beckmann, M., van der Knaap, W.O., Curdy, P., Tinner, W., 2013. Changes in biodiversity and vegetation composition in the central Swiss Alps during the transition from pristine forest to first farming. Divers. Distrib. 19, 157-170. https://doi.org/10.1111/j.1472-4642.2012.00930.x.

Connor, S.E., Vannière, B., Colombaroli, D., Anderson, R.S., Carrión, J.S., Ejarque, A., Gil Romera, G., González-Sampériz, P., Hoefer, D., Morales-Molino, C. Revelles, J., Schneider, H., van der Knaap, W.O., van Leeuwen, J.F., Woodbridge, J., 2019. Humans take control of fire-driven diversity changes in Mediterranean Iberia's vegetation during the mid-late Holocene. Holocene 29, 886-901. https://doi.org/10.1177/0959683619826652.

Cugny, C., Mazier, F., Galop, D., 2010. Modern and fossil non-pollen palynomorphs from the Basque mountains (western Pyrenees, France): the use of coprophilous fungi to reconstruct pastoral activity. Veg. Hist. Archaeobotany 19, 391-408. https://doi.org/10.1007/s00334-010-0242-6.

Daley, T.J., Thomas, E.R., Holmes, J.A., Street-Perrott, F.A., Chapman, M.R., Tindall, J.C., Valdes, P.J., Loader, N.J., Marshall, J.D., Wolff, E.W., Hopley, P.J., Atkinson, T., Barber, K.E., Fisher, E.H., Robertson, I., Hughes, P.D.M., Roberts, C.N., 2011. The $8200 y r$ BP cold event in stable isotope records from the North Atlantic region. Global Planet. Change 79, 288-302. https://doi.org/10.1016/ j.gloplacha.2011.03.006.

Dean, J.R., Jones, M.D., Leng, M.J., Noble, S.R., Metcalfe, S.E., Sloane, H.J., Sahy, D., Eastwood, W.J., Roberts, C.N., 2015. Eastern Mediterranean hydroclimate over the late glacial and Holocene, reconstructed from the sediments of Nar lake, central Turkey, using stable isotopes and carbonate mineralogy. Quat. Sci. Rev. 124, 162-174. https://doi.org/10.1016/j.quascirev.2015.07.023.

Debret, M., Sebag, D., Desmet, M., Balsam, W., Copard, Y., Mourier, B., Susperrigui, A.-S., Arnaud, F., Bentaleb, I., Chapron, E., Lallier-Vergès, E., Winiarski, T., 2011. Spectrocolorimetric interpretation of sedimentary dynamics: the new "Q7/4 diagram. Earth Sci. Rev. 109, 1-19. https://doi.org/ 10.1016/j.earscirev.2011.07.002

Develle, A.-L., Williamson, D., Gasse, F., Walter-Simonnet, A.-V., 2009. Early Holocene volcanic ash fallout in the Yammoûneh lacustrine basin (Lebanon): tephrochronological implications for the Near East. J. Volcanol. Geoth. Res. 186, 416-425. https://doi.org/10.1016/j.jvolgeores.2009.07.016.

Douka, K., Efstratiou, N., Hald, M.M., Henriksen, P.S., Karetsou, A., 2017. Dating Knossos and the arrival of the earliest neolithic in the southern Aegean. Antiquity 91, 304-321. https://doi.org/10.15184/aqy.2017.29.

Doyen, E., Bégeot, C., Simonneau, A., Millet, L., Chapron, E., Arnaud, F., Vannière, B., 2016. Land use development and environmental responses since the Neolithic around Lake Paladru in the French Pre-alps. J. Archaeol. Sci.: Rep. 7, 48-59. https://doi.org/10.1016/j.jasrep.2016.03.040.

Driessen, J., 2019. The Santorini eruption. An archaeological investigation of its distal impacts on Minoan Crete. Quat. Int. 499, 195-204. https://doi.org/ 10.1016/j.quaint.2018.04.019.

Druitt, T.H., Mellors, R.A., Pyle, D.M., Sparks, R.S.J., 1989. Explosive volcanism on Santorini, Greece. Geol. Mag. 126, 95-126. https://doi.org/10.1017/ S0016756800006270.

Druitt, T.H., Brenchley, P.J., Gökten, Y.E., Francaviglia, V., 1995. Late quaternary rhyolitic eruptions from the Acigöl complex, central Turkey. J. Geol. Soc. 152, 655-667. https://doi.org/10.1144/gsjgs.152.4.0655.

Druitt, T.H. (Ed.), 1999. Santorini Volcano. Geological Society memoir. Geological Society ; AAPG Bookstore [distributor], London : Tulsa, OK.

Dusar, B., Verstraeten, G., Notebaert, B., Bakker, J., 2011. Holocene environmental change and its impact on sediment dynamics in the Eastern Mediterranean. Earth Sci. Rev. 108, 137-157. https://doi.org/10.1016/j.earscirev.2011.06.006.

Efstratiou, N., 2013. The stratigraphy and cultural phases. In: Efstratiou, N. (Ed.), The Neolithic Settlement of Knossos in Crete. New Evidence for the Early Occupation of Crete and the Aegean Islands, Prehistory Monographs 42. INSTAP Academic Press, Philadelphia, Pennsylvania, pp. 25-46.

Efstratiou, N., Karetsou, A., Ntinou, M. (Eds.), 2013. The Neolithic Settlement of Knossos in Crete. New Evidence for the Early Occupation of Crete and the Aegean Islands. INSTAP Academic Press, Philadelphia.

Elitok, Ö., Kamaci, Z., Dolmaz, M.N., Yilmaz, K., Sener, M., 2019. Relationship between chemical composition and magnetic susceptibility in the alkaline volcanics from the Isparta area, SW Turkey. J. Earth Syst. Sci. 119, 853-860.

Engel, M., Knipping, M., Brückner, H., Kiderlen, M., Kraft, J.C., 2009. Reconstructing middle to late Holocene palaeogeographies of the lower Messenian plain (southwestern Peloponnese, Greece): coastline migration, vegetation history and sea level change. Palaeogeogr. Palaeoclimatol. Palaeoecol. 284, 257-270. https://doi.org/10.1016/j.palaeo.2009.10.005.

Etienne, D., Jouffroy-Bapicot, I., 2014. Optimal counting limit for fungal spore abundance estimation using Sporormiella as a case study. Veg. Hist. Archaeobotany 23, 743-749. https://doi.org/10.1007/s00334-014-0439-1.

Etienne, D., Wilhelm, B., Sabatier, P., Reyss, J.-L., Arnaud, F., 2013. Influence of sample location and livestock numbers on Sporormiella concentrations and accumulation rates in surface sediments of Lake Allos, French Alps. J. Paleolimnol. 49, 117-127. https://doi.org/10.1007/s10933-012-9646-x.

Facorellis, Y. Maniatis, Y, 2013. Radiocarbon dates from the Neolithic settlement of Knossos - an overview. In: The Neolithic Settlement of Knossos in Crete. New Evidence for the Early Occupation of Crete and the Aegean Islands, Prehistory Monographs, vol. 42. INSTAP Academic Press, Philadelphia, Penssylvania, pp. 193-200.

Faegri, K., Iversen, J., 1989. Textbook of Pollen Analysis, 4e ed. John Wiley \& Sons, Chichester-New York-Brisbane-Toronto-Singapore.

Field, S., 2015. Mediterranean Climate and Environmental Change during the Holocene: Evidence from Lake Kournas, Crete, Using Diatom Assemblages. Unpublished MSc dissertation. University of Plymouth, Plymouth. 
Fielding, J., Turland, N., 2008. Flowers of Crete. Royal Botanic Garden, Kew.

Finné, M., Bar-Matthews, M., Holmgren, K., Sundqvist, H.S., Liakopoulos, I., Zhang, Q., 2014. Speleothem evidence for late Holocene climate variability and floods in Southern Greece. Quat. Res. 81, 213-227. https://doi.org/10.1016/ j.yqres.2013.12.009.

Finné, M., Woodbridge, J., Labuhn, I., Roberts, C.N., 2019. Holocene hydro-climatic variability in the Mediterranean: a synthetic multi-proxy reconstruction. Holocene 29, 847-863. https://doi.org/10.1177/0959683619826634.

Finsinger, W., Tinner, W., 2005. Minimum count sums for charcoal concentration estimates in pollen slides: accuracy and potential errors. Holocene 15, 293-297. https://doi.org/10.1191/0959683605hl808rr.

Florenzano, A., Marignani, M., Rosati, L., Fascetti, S., Mercuri, A.M., 2015. Are Cichorieae an indicator of open habitats and pastoralism in current and past vegetation studies? Plant Biosyst. - Int. J. Deal. Aspect. Plant Biol. 149, 154-165. https://doi.org/10.1080/11263504.2014.998311.

Foxhall, L., 2007. Olive Cultivation in Ancient Greece: Seeking the Ancient Economy. OUP Oxford, Oxford.

Friedrich, W.L., 2006a. Santorini eruption radiocarbon dated to 1627-1600 B.C. Science 312. https://doi.org/10.1126/science.1125087, 548-548.

Friedrich, W.L., 2006b. Santorini eruption radiocarbon dated to 1627-1600 B.C. Science 312. https://doi.org/10.1126/science.1125087, 548-548.

Fuchs, M., 2007. An assessment of human versus climatic impacts on Holocene soil erosion in NE Peloponnese, Greece. Quat. Res. 67, 349-356. https://doi.org/ 10.1016/j.yqres.2006.11.008.

Gallimore, S.C., 2011. An Island Economy: Ierapetra and Crete in the Roman Empire. ProQuest Dissertations and Theses).

Gallimore, S., 2017. Food surplus and archaeological proxies: a case study from Roman Crete. World Archaeol. 49, 138-150. https://doi.org/10.1080/ 00438243.2016.1259582.

Ghilardi, M., Psomiadis, D., Andrieu-Ponel, V., Colleu, M., Sotiropoulos, P., Longo, F., Rossi, A., Amato, V., Gasse, F., Sinibaldi, L., Renard, M., Bicket, A., Delanghe, D., Demory, F., Fleury, J., 2018. First evidence of a lake at ancient Phaistos (Messara Plain, south-central Crete, Greece): reconstructing paleoenvironments and differentiating the roles of human land-use and paleoclimate from minoan to roman times. Holocene 28, 1225-1244. https://doi.org/10.1177/ 0959683618771473.

Ghilardi, M., Revelles, J., Glais, A., Theodorakopoulou, K., Theodoropoulou, T., Lespez, L., Longo, F., Rossi, A., Bellier, O., Benedetti, L., Fleury, J., 2019. Reconstructing human-environment interactions in the western Messara Plain (Phaistos, Crete, Greece) from the emergence of city states to Byzantine times. J. Archaeol. Sci: Rep. 26, 101909. https://doi.org/10.1016/j.jasrep.2019.101909.

Giguet-Covex, C., Arnaud, F., Poulenard, J., Disnar, J.-R., Delhon, C., Francus, P., David, F., Enters, D., Rey, P.-J., Delannoy, J.-J., 2011. Changes in erosion patterns during the Holocene in a currently treeless subalpine catchment inferred from lake sediment geochemistry (Lake Anterne, $2063 \mathrm{~m}$ a.s.l., NW French Alps): the role of climate and human activities. Holocene 21, 651-665. https://doi.org/ $10.1177 / 0959683610391320$.

Giguet-Covex, C., Arnaud, F., Enters, D., Poulenard, J., Millet, L., Francus, P., David, F., Rey, P.-J., Wilhelm, B., Delannoy, J.-J., 2012. Frequency and intensity of highaltitude floods over the last $3.5 \mathrm{ka}$ in northwestern French Alps (Lake Anterne). Quat. Res. 77, 12-22. https://doi.org/10.1016/j.yqres.2011.11.003.

Gilli, A., Anselmetti, F.S., Glur, L., Wirth, S.B., n.d. Lake sediments as archives of recurrence rates and intensities of past flood events, in: SchneuwlyBollschweiler, M., Stoffel, M., Rudolf-Miklau, F. (Eds.), Dating Torrential Processes on Fans and Cones - Methods and Their Application for Hazard and Risk Assessment., Advances in Global Change Research. pp. 225-242.

Giorgi, F., 2006. Climate change hot-spots. Geophys. Res. Lett. 33, L08707. https:// doi.org/10.1029/2006GL025734.

Goedecke, F., Jahn, R., Bergmeier, E., 2018. Quantified ecology and co-occurrence of Mediterranean woody species in a landscape context. Plant Ecol. 219, 481-496. https://doi.org/10.1007/s11258-018-0810-x.

Gogou, A., Bouloubassi, I., Lykousis, V., Arnaboli, M., Gaitani, P., Meyers, P.A., 2007. Organic geochemical evidence of Late Glacial-Holocene climate instability in the North Aegean Sea. Palaeogeography, Palaeoclimatology, Palaeoecology 256 (1-2), 1-20. https://doi.org/10.1016/j.palaeo.2007.08.002.

Graf, M.-T., Chmura, G.L., 2006. Development of modern analogues for natural, mowed and grazed grasslands using pollen assemblages and coprophilous fungi. Rev. Palaeobot. Palynol. 141, 139-149. https://doi.org/10.1016/ j.revpalbo.2006.03.018.

Grimm, E.C., 1991. Grimm, E. 2004. Tilia and TGView Version 2.0.2. Illinois State Museum.

Hamann, Y., Wulf, S., Ersoy, O., Ehrmann, W., Aydar, E., Schmiedl, G., 2010. First evidence of a distal early Holocene ash layer in Eastern Mediterranean deep-sea sediments derived from the anatolian volcanic province. Quat. Res. 73, 497-506. https://doi.org/10.1016/j.yqres.2009.12.004.

Hamilakis, Y., 1996. Wine, oil and the dialectics of power in Bronze Age Crete: a review of the evidence. Oxford J Archeol 15, 1-32. https://doi.org/10.1111/ j.1468-0092.1996.tb00071.x.

Harris, W.V., 1999. Crete in the Hellenistic and roman economies: a comment. In: Chaniotis, A. (Ed.), From Minoan Farmers to Roman Traders. Sidelights on the Economy of Ancient Crete. Franz Steiner Verlag, Stuttgart, pp. 353-358.

Hooke, J.M., 2006. Human impacts on fluvial systems in the Mediterranean region. Geomorphology 79, 311-335. https://doi.org/10.1016/j.geomorph.2006.06.036.

Horwitz, L.K., 2013. The earliest settlement of Crete: an archaeozoological perspective. In: Efstratiou, N., Dartsou, A., Ntinou, M. (Eds.), The Neolithic
Settlement of Knossos in Crete. New Evidence for the Early Occupation of Crete and the Aegean Islands. Efstratiou N., Dartsou A. Ntinou M., Philadelphia USA, pp. $171-192$.

IPBS Report, 2019. https://ipbes.net/global-assessment.

IPCC Report, 2019. https://www.ipcc.ch/2019/.

Ispikoudis, I., Lyrintzis, G., Kyriakakis, S., 1993. Impact of human activities on Mediterranean landscapes in western Crete. Landsc. Urban Plann. 24, 259-271. https://doi.org/10.1016/0169-2046(93)90105-M.

Izdebski, A., Słoczyński, T., Bonnier, A., Koloch, G., Kouli, K., 2020. Landscape change and trade in ancient Greece: evidence from pollen data. Econ. J. 130, 2596-2618. https://doi.org/10.1093/ej/ueaa026.

Jankovská, V., Komárek, J., 2000. Indicative value of Pediastrum and other coccal green algae in palaeoecology. Folia Geobot. 35, 59-82. https://loi.org/10.1007/ BF02803087.

John, J., Economou-Amilli, A., 1990. Cyclotella cretica, a new species of diatom from the island of Creta, Greece. Diatom Res. 5, 43-50.

John, J., Economou-Amilli, A., 1991. Morphology and ultrastructure of the centric diatom Cyclotella distinguenda. Diatom Res. 6, 307-315.

Jouffroy-Bapicot, I., Vannière, B., Iglesias, V., Debret, M., Delarras, J.-F., 2016. 2000 Years of grazing history and the making of the cretan mountain landscape, Greece. PloS One 11, e0156875. https://doi.org/10.1371/journal.pone.0156875.

Juggins, S., 2003. C2 Data Analysis: University of Newcastle, Version 1.4.3.

Juggins, S., 2015. European Diatom Database. Online: http://craticula.ncl.ac.uk/Eddi/ jsp/index.jsp. Accessed: 2011-2015.

Jusseret, S., Sintubin, M. (Eds.), 2017. Minoan Earthquakes: Breaking the Myth through Interdisciplinarity. Leuven University Press.

Jusseret, S., Langohr, C., Sintubin, M., 2013. Tracking earthquake archaeological evidence in late minoan IIIB ( $1300-1200$ B.C.) Crete (Greece): a proof of Concept. Bull. Seismol. Soc. Am. 103, 3026-3043. https://doi.org/10.1785/ 0120130070.

Kaniewski, D., Van Campo, E., Guiot, J., Le Burel, S., Otto, T., Baeteman, C., 2013. Environmental roots of the late bronze age crisis. PloS One 8, e71004. https:// doi.org/10.1371/journal.pone.0071004.

Karamesouti, M., Detsis, V., Kounalaki, A., Vasiliou, P., Salvati, L., Kosmas, C., 2015. Land-use and land degradation processes affecting soil resources: evidence from a traditional Mediterranean cropland (Greece). Catena 132, 45-55. https://doi.org/10.1016/j.catena.2015.04.010.

Killen, J., 2016. Wheat, Barley, Flour, olives and figs on linear B tablets. In: Food, Cuisine and Society in Prehistoric Greece. Oxbow Books. https://doi.org/ 10.2307/j.ctvh1drns.12.

Knapp, A.B., Manning, S.W., 2016. Crisis in context: the end of the late bronze age in the eastern Mediterranean. Am. J. Archaeol. 120, 99. https://doi.org/10.3764/ aja.120.1.0099.

Kołaczek, P., Zubek, S., Błaszkowski, J., Mleczko, P., Margielewski, W., 2013. Erosion or plant succession - how to interpret the presence of arbuscular mycorrhizal fungi (Glomeromycota) spores in pollen profiles collected from mires. Rev. Palaeobot. Palynol. 189, 29-37. https://doi.org/10.1016/j.revpalbo.2012.11.006.

Kosmas, C., Karamesouti, M., Kounalaki, K., Detsis, V., Vassiliou, P., Salvati, L., 2016. Land degradation and long-term changes in agro-pastoral systems: an empirical analysis of ecological resilience in Asteroussia - Crete (Greece). Catena 147, 196-204. https://doi.org/10.1016/j.catena.2016.07.018.

Kouli, K., Gogou, A., Bouloubassi, I., Triantaphyllou, M.V., Ioakim, Chr, Katsouras, G., Roussakis, G., Lykousis, V., 2012. Late postglacial paleoenvironmental change in the northeastern Mediterranean region: combined palynological and molecular biomarker evidence. Quat. Int. 261, 118-127. https://doi.org/10.1016/ j.quaint.2011.10.036.

Kouli, K., Masi, A., Mercuri, A.M., Florenzano, A., Sadori, L., 2018. Environment and Society in the Long Late Antiquity, Late Antique Archaeology, pp. 69-82. Leiden.

Krammer, K., Lange-Bertalot, H., 1991a. Bacillariophyceae 3. Teil centrales, Fragilariaceae, eunotiaceae. In: Ettl, H., Gärtner, G., Gerloff, J., Heynig, H., Mollenhauer, D. (Eds.), Süsswasserflora von Mitteleuropa. Gustav Fischer Verlag, Stuttgart.

Krammer, K., Lange-Bertalot, H., 1991b. Bacillariophyceae 4. Teil Achnanthaceae Kritische Ergänzungen zu Navicula (Lineolatae) und Gomphonema. In: Ettl, H., Gärtner, G., Gerloff, J., Heynig, H., Mollenhauer, D. (Eds.), Süsswasserflora von Mitteleuropa. Gustav Fischer Verlag, Stuttgart.

Krammer, K., Lange-Bertalot, H., 1997a. Bacillariophyceae 1. Teil naviculaceae. In: Ettl, H., Gärtner, G., Gerloff, J., Heynig, H., Mollenhauer, D. (Eds.), Süsswasserflora von Mitteleuropa. Gustav Fischer Verlag, Stuttgart.

Krammer, K., Lange-Bertalot, H., 1997b. Bacillariophyceae 2. Teil Bacillariaceae, epithemiaceae, surirellaceae. In: Ettl, H., Gärtner, G., Gerloff, J., Heynig, H., Mollenhauer, D. (Eds.), Süsswasserflora von Mitteleuropa. Gustav Fischer Verlag, Stuttgart.

Krammer, K., Lange-Bertalot, H., 2000. Bacillariophyceae Part 5. English and French translation of the keys. In: Ettl, H., Gärtner, G., Gerloff, J., Heynig, H. Mollenhauer, D. (Eds.), Süsswasserflora von Mitteleuropa. Gustav Fischer Verlag, Stuttgart.

Langgut, D., Cheddadi, R., Carrión, J.S., Cavanagh, M., Colombaroli, D., Eastwood, W.J., Greenberg, R., Litt, T., Mercuri, A.M., Miebach, A., Roberts, C.N., Woldring, H., Woodbridge, J., 2019. The origin and spread of olive cultivation in the Mediterranean Basin: the fossil pollen evidence. Holocene 29, 902-922. https://doi.org/10.1177/0959683619826654.

Lawson, I.T., Tzedakis, P.C., Roucoux, K.H., Galanidou, N., 2013. The anthropogenic influence on wildfire regimes: charcoal records from the Holocene and Last Interglacial at Ioannina, Greece. J. Biogeogr. 40, 2324-2334. https://doi.org/ 
10.1111/jbi.12164

Lespez, L., 2003. Geomorphic responses to long-term land use changes in Eastern Macedonia (Greece). Catena 51, 181-208. https://doi.org/10.1016/S03418162(02)00164-9.

Lestienne, M., Jouffroy-Bapicot, I., Leyssenne, D., Sabatier, P., Debret, M., Albertini, P.J., Colombaroli, D., Didier, J., Hély, C., Vannière, B., 2020. Fires and human activities as key factors in the high diversity of Corsican vegetation. Holocene 30, 244-257. https://doi.org/10.1177/0959683619883025.

Livarda, A., Orengo, H.A., Cañellas-Boltà, N., Riera-Mora, S., Picornell-Gelabert, L., Tzevelekidi, V., Veropoulidou, R., Marlasca Martín, R., Krahtopoulou, A., 2021. Mediterranean polyculture revisited: olive, grape and subsistence strategies at Palaikastro, East Crete, between the late neolithic and late bronze age. J. Anthropol. Archaeol. 61, 101271. https://doi.org/10.1016/j.jaa.2021.101271.

Macklin, M.G., Tooth, S., Brewer, P.A., Noble, P.L., Duller, G.A.T., 2010. Holocene flooding and river development in a Mediterranean steepland catchment: the Anapodaris Gorge, south central Crete, Greece. Global Planet. Change 70, 35-52. https://doi.org/10.1016/j.gloplacha.2009.11.006.

Magny, M., Combourieu-Nebout, N., de Beaulieu, J.L., Bout-Roumazeilles, V., Colombaroli, D., Desprat, S., Francke, A., Joannin, S., Ortu, E., Peyron, O., Revel, M., Sadori, L., Siani, G., Sicre, M.A., Samartin, S., Simonneau, A., Tinner, W., Vannière, B., Wagner, B., Zanchetta, G., Anselmetti, F., Brugiapaglia, E., Chapron, E., Debret, M., Desmet, M., Didier, J., Essallami, L., Galop, D., Gilli, A., Haas, J.N., Kallel, N., Millet, L., Stock, A., Turon, J.L., Wirth, S., 2013. North-south palaeohydrological contrasts in the central Mediterranean during the Holocene: tentative synthesis and working hypotheses. Clim. Past 9, 2043-2071. https:// doi.org/10.5194/cp-9-2043-2013.

Marianelli, P., Sbrana, A., 1998. Risultati di misure di standard di minerali e di vetri naturali in microanalisi a dispersione di energia. Atti della Soc. Toscaná Sci. Nat. Ser. A 105, 57-63.

Marriner, N., Kaniewski, D., Gambin, T., Gambin, B., Vannière, B., Morhange, C., Djamali, M., Tachikawa, K., Robin, V., Rius, D., Bard, E., 2019. Fire as a motor of rapid environmental degradation during the earliest peopling of Malta 7500 years ago. Quat. Sci. Rev. 212, 199-205. https://doi.org/10.1016/ j.quascirev.2019.03.001.

Martín-Puertas, C., Valero-Garcés, B.L., Mata, M.P., Moreno, A., Giralt, S., MartínezRuiz, F., Jiménez-Espejo, F., 2011. Geochemical processes in a Mediterranean Lake: a high-resolution study of the last 4,000 years in Zoñar Lake, southern Spain. J. Paleolimnol. 46, 405-421. https://doi.org/10.1007/s10933-009-9373-0.

Martlew, Martlew, H., 1999. A vegetable stew at Gerani Cave, 1999. In: Tzedakis, Y., Martlew, H. (Eds.), Minoans and Mycenaeans: Flavours of Their Time. Ministry of Culture, Athens, p. 80.

Mayewski, P.A., Rohling, E.E., Curt Stager, J., Karlén, W., Maasch, K.A., Meeker, L.D., Meyerson, E.A., Gasse, F., van Kreveld, S., Holmgren, K., Lee-Thorp, J., Rosqvist, G., Rack, F., Staubwasser, M., Schneider, R.R., Steig, E.J., 2004. Holocene climate variability. Quat. Res. 62, 243-255. https://doi.org/10.1016/ j.yqres.2004.07.001.

McCarthy, F.M.G., Krueger, A.M., 2013. Freshwater dinoflagellates in palaeolimnological studies: Peridinium cysts as proxies of cultural eutrophication in the SE Great Lakes region of Ontario, Canada. In: Biological and Geological Perspectives of Dinoflagellates. Special Publications, Geological Society. The Micropalaeoontological Society, London, pp. 133-139.

McCarthy, F.M.G., Riddick, N.L., Volik, O., Danesh, D.C., Krueger, A.M., 2018. Algal palynomorphs as proxies of human impact on freshwater resources in the Great Lakes region. Anthropocene 21, 16-31. https://doi.org/10.1016/ j.ancene 201711.004.

Mix, A.C., Rugh, W., Pisias, N.G., Veirs, S., 1992. Color reflectance spectroscopy: a tool for rapid characterization of deep sea sediments. In: Proceedings of the Ocean Drilling Program,//Initial Repts. College Station, Tex. Ocean Drilling Program, Texas A \& M University, pp. 67-77.

Moody, J., Rackham, O., Rapp, G., 1996. Environmental archaeology of Prehistoric NW Crete. J. Field Archaeol. 23, 273-297. https://doi.org/10.1179/ 009346996791973855.

Moody, J., 2012. Hinterlands and hinterseas: resources and production zones in bronze age and Iron age Crete? In: parallel lives: ancient island societies in Crete and Cyprus. Brit. Sch. Athens Stud. 20, 233-271. https://www.jstor.org/ stable/23541212.

Moreira, F., Herrera, J.M., Beja, P., 2019. Making olive oil sustainable. Science 365, 873. https://doi.org/10.1126/science.aay7899.

Mourtzas, N., Kolaiti, E., Anzidei, M., 2016. Vertical land movements and sea level changes along the coast of Crete (Greece) since Late Holocene. Quat. Int. 401, 43-70. https://doi.org/10.1016/j.quaint.2015.08.008.

Nixon, L., Price, S., Rackham, O., Moody, J., 2009. Settlement patterns in medieval and post-medieval sphakia: issues from the archaeological and historical evidence. In: Bintliff, J., Stöger, H. (Eds.), Medieval and Post- Medieval Greece: the Corfu Papers. Archaeopress, 395-324.

Nowicki, K., 2014. Final Neolithic Crete and the Southeast Aegean. De Gruyter, Boston/Berlin.

Polonia, A., Torelli, L., Artoni, A., Carlini, M., Faccenna, C., Ferranti, L., Gasperini, L., Govers, R., Klaeschen, D., Monaco, C., Neri, G., Nijholt, N., Orecchio, B., Wortel, R., 2016. The Ionian and Alfeo-Etna fault zones: new segments of an evolving plate boundary in the central Mediterranean Sea? Tectonophysics 675, 69-90. https://doi.org/10.1016/j.tecto.2016.03.016.

Pomoni-Papaioannou, I., Karakitsios, V., 2002. Facies analysis of the Trypali carbonate unit (Upper Triassic) in central-western Crete (Greece): an evaporite formation transformed into solution-collapse breccias. Sedimentology 49.
Pearson, C.L., Dale, D.S., Brewer, P.W., Kuniholm, P.I., Lipton, J., Manning, S.W., 2009. Dendrochemical analysis of a tree-ring growth anomaly associated with the Late Bronze Age eruption of Thera. J. Archaeol. Sci. 36, 1206-1214. https:// doi.org/10.1016/j.jas.2009.01.009.

Peinerud, E.K., Ingri, J., Pontér, C., 2001. Non-detrital Si concentrations as an estimate of diatom concentrations in lake sediments and suspended material. Chem. Geol. 177, 229-239. https://doi.org/10.1016/S0009-2541(00)00378-8.

Perissoratis, C., Conispoliatis, N., 2003. The impacts of sea-level changes during latest Pleistocene and Holocene times on the morphology of the Ionian and Aegean seas (SE Alpine Europe). Mar. Geol. 196, 145-156. https://doi.org/ 10.1016/S0025-3227(03)00047-1.

Pross, J., Kotthoff, U., Müller, U.C., Peyron, O., Dormoy, I., Schmiedl, G., Kalaitzidis, S., Smith, A.M., 2009. Massive perturbation in terrestrial ecosystems of the Eastern Mediterranean region associated with the $8.2 \mathrm{kyr}$ B.P. Clima. Event Geol. 37, 887-890. https://doi.org/10.1130/G25739A.1.

Rackham, O., Moody, J., 1996. The Making of the Cretan Landscape. Manchester University Press, Manchester.

Rapuc, W., Sabatier, P., Arnaud, F., Palumbo, A., Develle, A.-L., Reyss, J.-L., Augustin, L., Régnier, E., Piccin, A., Chapron, E., Dumoulin, J.-P., von Grafenstein, U., 2019. Holocene-long record of flood frequency in the Southern Alps (Lake Iseo, Italy) under human and climate forcing. Global Planet. Change 175, 160-172. https://doi.org/10.1016/j.gloplacha.2019.02.010.

Reille, M., 1999. Pollen et spores d'Europe et d'Afrique du nord, 2. éd. Laboratoire de Botanique Historique et Palynologie, Marseille.

Reimer, P.J., Bard, E., Bayliss, A., Beck, J.W., Blackwell, P.G., Ramsey, C.B., Buck, C.E., Cheng, H., Edwards, R.L., Friedrich, M., Grootes, P.M., Guilderson, T.P., Haflidason, H., Hajdas, I., Hatté, C., Heaton, T.J., Hoffmann, D.L., Hogg, A.G., Hughen, K.A., Kaiser, K.F., Kromer, B., Manning, S.W., Niu, M., Reimer, R.W., Richards, D.A., Scott, E.M., Southon, J.R., Staff, R.A., Turney, C.S.M., van der Plicht, J., 2013. IntCal13 and Marine 13 radiocarbon age calibration curves 0-50,000 Years cal BP. Radiocarbon 55, 1869-1887. https://doi.org/10.2458/ azu_js_rc.55.16947.

Revel, M., Ducassou, E., Grousset, F.E., Bernasconi, S.M., Migeon, S., Revillon, S., Mascle, J., Murat, A., Zaragosi, S., Bosch, D., 2010. 100,000 Years of African monsoon variability recorded in sediments of the Nile margin. Quat. Sci. Rev. 29, 1342-1362. https://doi.org/10.1016/j.quascirev.2010.02.006.

Reyss, J.-L., Schmidt, S., Legeleux, F., Bonté, P., 1995. Large, low background welltype detectors for measurements of environmental radioactivity. Nucl. Instrum. Methods Phys. Res. Sect. A Accel. Spectrom. Detect. Assoc. Equip. 357, 391-397. https://doi.org/10.1016/0168-9002(95)00021-6.

Riley, F.R., 2002. Olive oil production on bronze age Crete: nutritional properties, processing methods and storage life of Minoan olive oil. Oxford J Archeol 21, 63-75. https://doi.org/10.1111/1468-0092.00149.

Riley, F.R., 2012. The olive industry of Bronze Age Crete: evidence for volcanic damage to olive groves and property in Central and Eastern Crete. AKR 49. https://doi.org/10.7445/49-0-82.

Roberts, N., Eastwood, W.J., Kuzucuoğlu, C., Fiorentino, G., Caracuta, V., 2011. Climatic, vegetation and cultural change in the eastern Mediterranean during the mid-Holocene environmental transition. Holocene 21, 147-162. https://doi.org/ 10.1177/0959683610386819.

Roberts, N., Allcock, S.L., Barnett, H., Mather, A., Eastwood, W.J., Jones, M., Primmer, N., Yiğitbașığlu, H., Vannière, B., 2018. Cause-and-effect in Mediterranean erosion: the role of humans and climate upon Holocene sediment flux into a central Anatolian lake catchment. Geomorphology 131, 36-48. https:/ doi.org/10.1016/j.geomorph.2018.11.016.

Rohling, E., Mayewski, P., Abu-Zied, R., Casford, J., Hayes, A., 2002. Holocene atmosphere-ocean interactions: records from Greenland and the Aegean Sea. Clim. Dynam. 18, 587-593. https://doi.org/10.1007/s00382-001-0194-8.

Rohling, E.J., Marino, G., Grant, K.M., 2015. Mediterranean climate and oceanography, and the periodic development of anoxic events (sapropels). Earth Sci. Rev. 143, 62-97. https://doi.org/10.1016/j.earscirev.2015.01.008.

Rohling, E.J., Marino, G., Grant, K.M., Mayewski, P.A., Weninger, B., 2019. A model for archaeologically relevant Holocene climate impacts in the Aegean-Levantine region (easternmost Mediterranean). Quat. Sci. Rev. 208, 38-53. https:// doi.org/10.1016/j.quascirev.2019.02.009.

Sabatier, P., Dezileau, L., Condomines, M., Briqueu, L., Colin, C., Bouchette, F., Le Duff, M., Blanchemanche, P., 2008. Reconstruction of paleostorm events in a coastal lagoon (Hérault, South of France). Mar. Geol. 251, 224-232. https:// doi.org/10.1016/j.margeo.2008.03.001.

Sabatier, P., Wilhelm, B., Ficetola, G.F., Moiroux, F., Poulenard, J., Develle, A.-L., Bichet, A., Chen, W., Pignol, C., Reyss, J.-L., Gielly, L., Bajard, M., Perrette, Y., Malet, E., Taberlet, P., Arnaud, F., 2017. 6-kyr record of flood frequency and intensity in the western Mediterranean Alps - interplay of solar and temperature forcing. Quat. Sci. Rev. 170, 121-135. https://doi.org/10.1016/ j.quascirev.2017.06.019.

Sarris, D., Christopoulou, A., Angelonidi, E., Koutsias, N., Fulé, P.Z., Arianoutsou, M., 2014. Increasing extremes of heat and drought associated with recent severe wildfires in southern Greece. Reg. Environ. Change 14, 1257-1268. https:// doi.org/10.1007/s10113-013-0568-6.

Stallsmith, A., 2007. One colony, two mother cities: cretan agriculture under Venetian and Ottoman rule. In: Between Venice and Istanbul: Colonial Landscapes in Early Modern Greece, Hesperia Supplement 40. The American School of Classical Studies at Athens, pp. 151-171.

Stivrins, N., Soininen, J., Tõnno, I., Freiberg, R., Veski, S., Kisand, V., 2018. Towards understanding the abundance of non-pollen palynomorphs: a comparison of 
fossil algae, algal pigments and sedaDNA from temperate lake sediments. Rev. Palaeobot. Palynol. 249, 9-15. https://doi.org/10.1016/j.revpalbo.2017.11.001.

Strasser, T.F., Murray, S.C., van der Geer, A., Kolb, C., Ruprecht, L.A., 2018. Palaeolithic cave art from Crete, Greece. J. Archaeol. Sci. Rep. 18, 100-108. https://doi.org/ 10.1016/J.JASREP.2017.12.041.

Sulpizio, R., Alçiçek, M.C., Zanchetta, G., Solari, L., 2013. Recognition of the Minoan tephra in the Acigöl Basin, western Turkey: implications for inter-archive correlations and fine ash dispersal: minoan tephra IN the acigöl basin, western Turkey. J. Quat. Sci. 28, 329-335. https://doi.org/10.1002/jqs.2630.

Tapoglou, E., Vozinaki, E.A., Tsanis, I., 2019. Climate Change Impact on the Frequency of Hydrometeorological Extremes in the Island of Crete. https://doi.org/ 10.3390/w11030587. Water 11

Thornes, J.B., Wainwright, J., 2004. Environmental Issues in the Mediterranean: Processes and Perspectives from the Past and Present, first ed. Routledge. https://doi.org/10.4324/9780203495490.

Tigilis, C., 2007. Study of the Ecosystem of Lake Kournas, Chania with Emphasis on Plankton and Ichthyopanida. Ph.D. Thesis. Department of Biology, University of Crete, Heraklion (in Greek).

Tinner, W., van Leeuwen, J.F.N., Colombaroli, D., Vescovi, E., van der Knaap, W.O., Henne, P.D., Pasta, S., D'Angelo, S., La Mantia, T., 2009. Holocene environmental and climatic changes at Gorgo Basso, a coastal lake in southern Sicily, Italy. Quat. Sci. Rev. 28, 1498-1510. https://doi.org/10.1016/j.quascirev.2009.02.001.

Tinner, W., Vescovi, E., van Leeuwen, J., Colombaroli, D., Henne, P., Kaltenrieder, P., Morales-Molino, C., Beffa, G., Gnaegi, B., van der Knaap, W.O., La Mantia, T., Pasta, S., 2016. Holocene vegetation and fire history of the mountains of Northern Sicily (Italy). Vegetation History and Archaeobotany 25 (5), 499-519.

Tjallingii, R., Röhl, U., Kölling, M., Bickert, T., 2007. Influence of the water content on $\mathrm{X}$-ray fluorescence core-scanning measurements in soft marine sediments: XRF core scanning. G-cubed 8. https://doi.org/10.1029/2006GC001393 n/a-n/a.

Tomkins, P., 2008. Time, space and the reinvention of the cretan neolithic. In: Issakidou, V., Tomkins, P.D. (Eds.), Escaping the Labyrinth. Oxbow, Oxford, pp. $21-48$.

Tomkins, P., 2018. About time. Rehabilitating chronology in the interpretation of settlement in East Crete between the neolithic and early minoan I. Creta Antica 19, 45-92.

Vacchi, M., Marriner, N., Morhange, C., Spada, G., Fontana, A., Rovere, A., 2016. Multiproxy assessment of Holocene relative sea-level changes in the western Mediterranean: sea-level variability and improvements in the definition of the isostatic signal. Earth Sci. Rev. 155, 172-197. https://doi.org/10.1016/ j.earscirev.2016.02.002.

van Geel, B., 2001. Non-pollen palynomorphs. In: Smol, J.P., Birks, J.B., Last, W.M. (Eds.), Developments in Paleoenvironmental Research. Presented at the Tracking Environmental Change Using Lake Sediments. Volume 3: Terrestrial, Algal, and Siliceous Indicators. Kluwer, pp. 99-119, 20/12/06.

van Geel, B., Aptroot, A., 2006. Fossil ascomycetes in Quaternary deposits. Nova Hedwigia 82, 313-329.

van Hunnik, E., van den Ende, H., Timmermans, K.R., Laan, P., de Leeuw, J.W., 2000. A comparison of $\mathrm{CO} 2$ uptake by the green algae Tetraedron minimum and Chlamydomonas monoica. Plant Biol. 2, 624-627. https://doi.org/10.1055/s2000-16637.

Vallianos, Ch, Theodoraki, M., Koubli, L., Murtzas, N., Vasilopoulos, P., Kainadas, El, 1985. Lake Kournas of Chania. Crete Museum Study. Eco-Development Programme, p. 65 (in Greek).

Vannière, B., Bossuet, G., Walter-Simonnet, A.-V., Ruffaldi, P., Adatte, T., Rossy, M., Magny, M., 2004. High-resolution record of environmental changes and tephrochronological markers of the last glacial-Holocene transition at lake Lautrey (Jura, France): last glacial-Holocene transition at lake Lautrey, France. J. Quat. Sci. 19, 797-808. https://doi.org/10.1002/jqs.873.

Vannière, B., Colombaroli, D., Chapron, E., Leroux, A., Tinner, W., Magny, M., 2008. Climate versus human-driven fire regimes in Mediterranean landscapes: the Holocene record of Lago dell'Accesa (Tuscany, Italy). Quat. Sci. Rev. 27, 1181-1196. https://doi.org/10.1016/j.quascirev.2008.02.011.

Vannière, B., Power, M.J., Roberts, N., Tinner, W., Carrión, J., Magny, M., Bartlein, P., Colombaroli, D., Daniau, A.L., Finsinger, W., Gil-Romera, G., Kaltenrieder, P., Pini, R., Sadori, L., Turner, R., Valsecchi, V., Vescovi, E., 2011. Circum-
Mediterranean fire activity and climate changes during the mid-Holocene environmental transition (8500-2500 cal. BP). Holocene 21, 53-73. https:// doi.org/10.1177/0959683610384164.

Vannière, B., Blarquez, O., Rius, D., Doyen, E., Brücher, T., Colombaroli, D., Connor, S., Feurdean, A., Hickler, T., Kaltenrieder, P., Lemmen, C., Leys, B., Massa, C., Olofsson, J., 2016. 7000-year human legacy of elevation-dependent European fire regimes. Quat. Sci. Rev. 132, 206-212. https://doi.org/10.1016/ j.quascirev.2015.11.012.

Vannière, B., Magny, M., Joannin, S., Simonneau, A., Wirth, S.B., Hamann, Y., Chapron, E., Gilli, A., Desmet, M., Anselmetti, F.S., 2013. Orbital changes, variation in solar activity and increased anthropogenic activities: controls on the Holocene flood frequency in the Lake Ledro area, Northern Italy. Clim. Past 9, 1193-1209. https://doi.org/10.5194/cp-9-1193-2013.

Vigne, J.-D., Briois, F., Zazzo, A., Willcox, G., Cucchi, T., Thiébault, S., Carrère, I., Franel, Y., Touquet, R., Martin, C., Moreau, C., Comby, C., Guilaine, J., 2012. First wave of cultivators spread to Cyprus at least 10,600 y ago. Proc. Natl. Acad. Sci. U.S.A. 109, 8445. https://doi.org/10.1073/pnas.1201693109.

Vita-Finzi, C., 1969. The Mediterranean Valleys: Geological Changes in Historical Times. University Press, Cambridge.

Vogiatzakis, I.N., Mannion, A.M., Sarris, D., 2016. Mediterranean island biodiversity and climate change: the last 10,000 years and the future. Biodivers. Conserv. 25, 2597-2627. https://doi.org/10.1007/s10531-016-1204-9.

Walsh, K., 2014. The Archaeology of Mediterranean Landscapes: HumanEnvironment Interaction from the Neolithic to the Roman Period. Cambridge University Press, Cambridge ; New York.

Walsh, K., Berger, J.-F., Roberts, C.N., Vanniere, B., Ghilardi, M., Brown, A.G., Woodbridge, J., Lespez, L., Estrany, J., Glais, A., Palmisano, A., Finné, M., Verstraeten, G., 2019. Holocene demographic fluctuations, climate and erosion in the Mediterranean: a meta data-analysis. Holocene 29, 864-885. https:// doi.org/10.1177/0959683619826637.

Weiberg, E., Unkel, I., Kouli, K., Holmgren, K., Avramidis, P., Bonnier, A., Dibble, F., Finné, M., Izdebski, A., Katrantsiotis, C., Stocker, S.R., Andwinge, M., Baika, K., Boyd, M., Heymann, C., 2016. The socio-environmental history of the Peloponnese during the Holocene: towards an integrated understanding of the past. Quat. Sci. Rev. 136, 40-65. https://doi.org/10.1016/j.quascirev.2015.10.042.

Weiberg, E., Bevan, A., Kouli, K., Katsianis, M., Woodbridge, J., Bonnier, A., Engel, M. Finné, M., Fyfe, R., Maniatis, Y., Palmisano, A., Panajiotidis, S., Roberts, C.N., Shennan, S., 2019. Long-term trends of land use and demography in Greece: a comparative study. Holocene 29, 742-760. https://doi.org/10.1177/ 0959683619826641.

Weninger, B., Clare, L., Rohling, E., Bar-Yosef, O., Böhner, U., Budja, M., Bundschuh, M., Feurdean, A., Gebe, H.G., Jöris, O., Linstädter, J., Mayewski, P., Mühlenbruch, T., Reingruber, A., Rollefson, G., Schyle, D., Thissen, L., Todorova, H., Zielhofer, C., 2009. The impact of rapid climate change on prehistoric societies during the Holocene in the eastern Mediterranean. Doc. praeh. 36, 7. https://doi.org/10.4312/dp.36.2.

Whitlock, C., Colombaroli, D., Conedera, M., Tinner, W., 2018. Land-use history as a guide for forest conservation and management. Conserv. Biol. 32, 84-97. https://doi.org/10.1111/cobi.12960.

Wiener, M.H., 2014. The interaction of climate change and agency in the collapse of civilizations ca. 2300-2000 BC. Radiocarbon 56, S1-S16. https://doi.org/ 10.2458 /azu_rc.56.18325.

Wilhelm, B., Arnaud, F., Sabatier, P., Magand, O., Chapron, E., Courp, T., Tachikawa, K., Fanget, B., Malet, E., Pignol, C., Bard, E., Delannoy, J.J., 2013. Palaeoflood activity and climate change over the last 1400 years recorded by lake sediments in the north-west European Alps. J. Quat. Sci. 28, 189-199. https://doi.org/10.1002/ jqs.2609.

Wilhelm, B., Vogel, H., Crouzet, C., Etienne, D., Anselmetti, F.S., 2016. Frequency and intensity of palaeofloods at the interface of Atlantic and Mediterranean climate domains. Clim. Past 12, 299-316. https://doi.org/10.5194/cp-12-299-2016.

Wulf, S., Keller, J., Satow, C., Gertisser, R., Kraml, M., Grant, K.M., Appelt, O., Vakhrameeva, P., Koutsodendris, A., Hardiman, M., Schulz, H., Pross, J., 2020. Advancing Santorini's tephrostratigraphy: new glass geochemical data and improved marine-terrestrial tephra correlations for the past $\sim 360$ kyrs. Earth Sci. Rev. 200, 102964. https://doi.org/10.1016/j.earscirev.2019.102964. 